*als View/Print Document Cover Sheet tow

This document was retrieved from the Boeing ISEARCH System.

Accession \#: D196071697

Document \#: SD-WM-ER-514

Title/Desc:

HEADSPACE GAS \& VAPOR CHARACTERIZATION SUMMARY FOR THE 43 VAPOR PROGRAM SUSPECT TANKS 


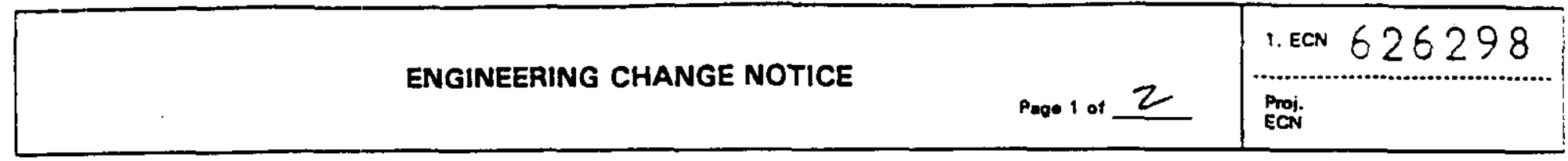

\begin{tabular}{|c|c|c|c|c|c|c|}
\hline \multirow{3}{*}{$\begin{array}{l}\text { 2. ECN Category } \\
\text { (mark one) } \\
\text { Supplemental } \\
\text { Direct Revision } \\
\text { Change ECN } \\
\text { Temporary } \\
\text { Standby } \\
\text { Supersedure } \\
\text { Cancel/Noid }\end{array}$} & \multirow{3}{*}{$\begin{array}{l}0] \\
x \\
0] \\
0] \\
0 \\
0\end{array}$} & \multicolumn{2}{|c|}{$\begin{array}{l}\text { 3. Originator's Name, Organization, MSiN, } \\
\text { and Telephone No. } \\
\text { D. R. BRATZEL, } 75640, S 7-21 \text {, } \\
\text { 373-3579 }\end{array}$} & \multicolumn{2}{|c|}{$\begin{array}{l}\text { 3a. USQ Required? } \\
\text { [] Yes }[X] \text { No }\end{array}$} & $\begin{array}{l}\text { 4. Date } \\
10 / 06 / 95\end{array}$ \\
\hline & & \multicolumn{2}{|c|}{$\begin{array}{l}\text { 5. Project Titte/No./Work order No. } \\
\text { HEADSPACE GAS AND VAPOR } \\
\text { CHARACTERIZATION SUMMARY FOR } \\
\text { THE } 43 \text { VAPOR PROGRAM SUSPECT } \\
\text { TANKS }\end{array}$} & \multicolumn{2}{|c|}{$\begin{array}{l}\text { 6. Bldg./Sys./Fac. No. } \\
2704 \mathrm{HV} / 200 \mathrm{E}\end{array}$} & $\begin{array}{l}\text { 7. Approval Designator } \\
\text { N/A }\end{array}$ \\
\hline & & \multicolumn{2}{|c|}{$\begin{array}{l}\text { 8. Document Numbers Changed by this ECN } \\
\text { (includes sheet no. and rev.) } \\
\text { WHC-SD-WM-ER-514 REV } 0\end{array}$} & \multicolumn{2}{|c|}{$\begin{array}{l}\text { 9. Related ECN No(s). } \\
\qquad N / A\end{array}$} & $\begin{array}{l}\text { 10. Related PO No. } \\
\qquad N / A\end{array}$ \\
\hline \multirow{2}{*}{\multicolumn{2}{|c|}{$\begin{array}{l}\text { 11a. Modification Work } \\
\text { [] Yes (fill out Blk. } \\
11 \mathrm{~b}) \\
{[X] \text { No (NA B(ks, 11b, }} \\
11 c, 11 d)\end{array}$}} & \multirow[t]{2}{*}{$\begin{array}{l}\text { 11b. Hork Package } \\
\text { No. } \\
\text { N/A }\end{array}$} & \multirow{2}{*}{\multicolumn{2}{|c|}{$\begin{array}{l}\text { 11c. Modification Work Complete } \\
\text { N/A }\end{array}$}} & \multicolumn{2}{|c|}{$\begin{array}{l}\text { 11d. Restored to Original Condi- } \\
\text { tion (Temp. or Standby ECN only) } \\
\text { N/A }\end{array}$} \\
\hline & & & & & Cog. & neer signature \& De \\
\hline
\end{tabular}

12. Description of Change

- Inclusion of the toxicology review panel analytes of concern (Table 2) in the main body of the report.

- Modification of 29 CFR 1910.1016 as an OSHA standard (not as a NIOSH exposure limit)

in section 2.2.4.

- Addition of sample analysis dates and holding times in Table 1.

- Identification of whether analytical results were obtained using the vapor sampling system (VSS) or in situ sampling system (ISS).

13a. Justification (mark one)

Criteria Change [X] Design Improvenent [] Environmental

As-Found

[] Facilitate const

[] Const. Error/Omission []

Facility Deactivation

Design Error/Omission

[]

13b. Justification Details

This revision of the document includes relatively minor comments for clarification of data results and qualification of data. A complete revision is being issued to assure re-distribution of the entire document.

14. Distribution (include name, MSIN, and no. of copies)

See attached Distribution Sheet

RELEASE STAMP

OFFICIAL RELEASE BY WHC

DATE CCT O 61995

$\operatorname{sta} 4$ 


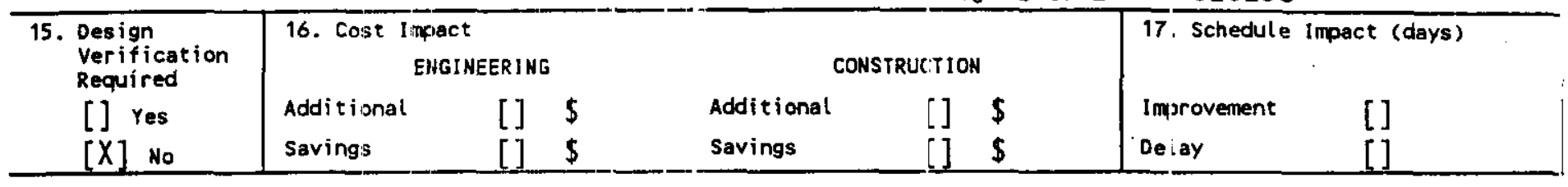



19. Other Affected Documents: (NOTE: Documents listed below will not be revised by this ECN.) Signatures below indicate that the signing organization has been notified of other affected documents listed below. Document Number/Revision Document Number/Revision Document Number Revision

20. Approvals

\section{Signat:ure}

OPERATIONS AND ENGINEERIMG

Cog. Eng. D. R. Bratzel $23 B$ - $\hat{j}$

Cog. Mgr. T. ง. Kelley 7 Clesy QA

Safety

Environ.

other

Proj.

Proj.

Proj.

Proj.

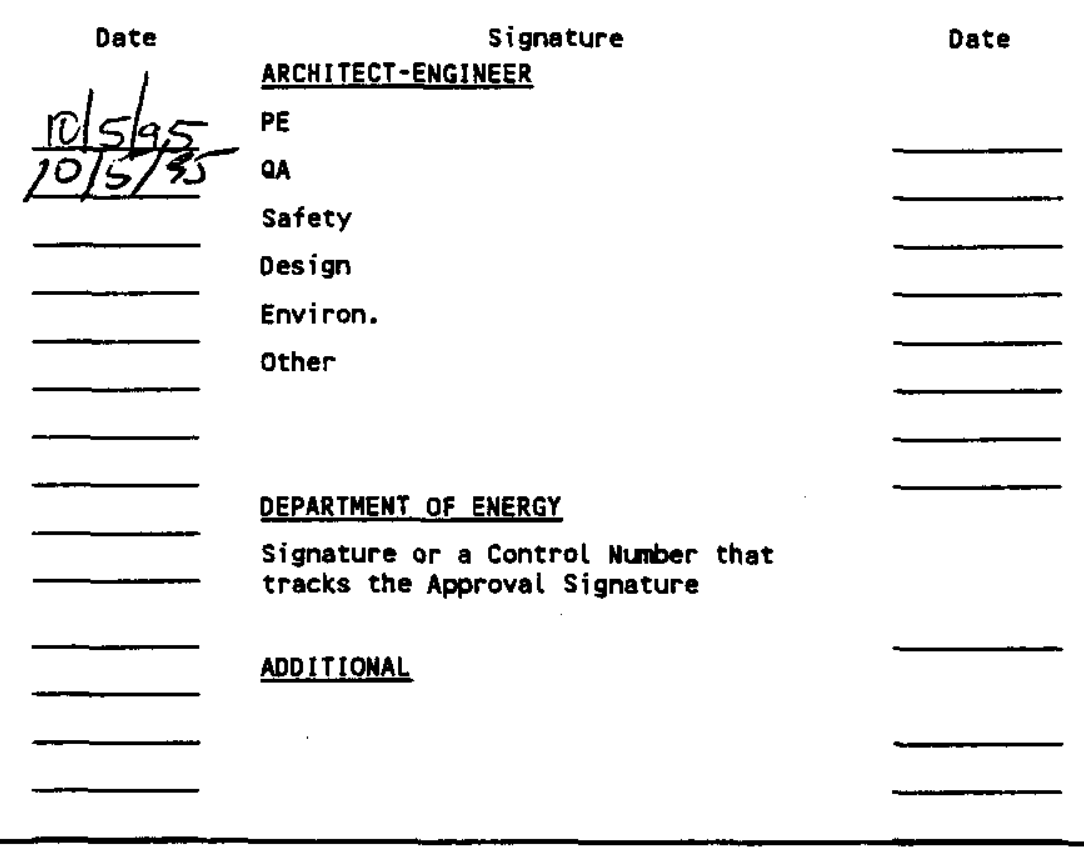




\section{RELEASE AUTHORIZATION}

\begin{tabular}{ll} 
Document Number: & WHC-SD-WM-ER-514, REV 1 \\
\hline Document Title: & $\begin{array}{l}\text { Headspace Gas and Vapor Characterization Summary for } \\
\text { the } 43 \text { Vapor Program Suspect Tanks }\end{array}$
\end{tabular}

Release Date: $\quad$ 10/5/95

This document was reviewed following the procedures described in WHC-CM-3-4 and is:

APPROVED FOR PUBLIC RELEASE

WHC Information Release Administration Specialist:
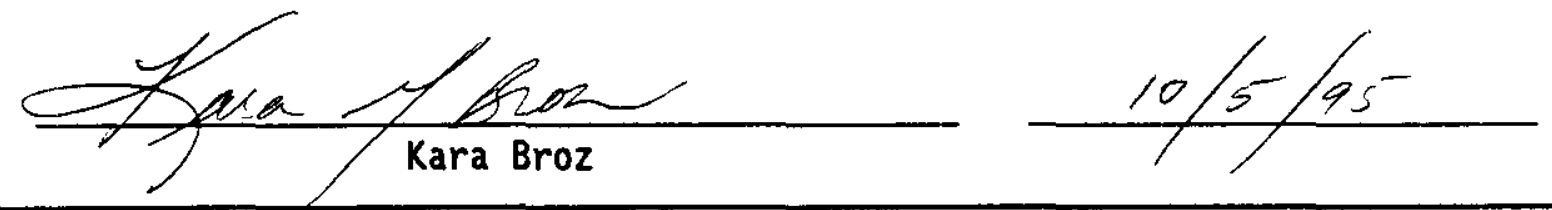

TRADEMARK DISCLAIMER. Reference here in to any specific commercial product, process, or service by trade name, trademark, manufacturer, or otherwise, does not necessarily constitute or imply its endorsement, recommendation, or favoring by the United States Government or any agency thereof or its contractors or subcontractors.

This report has been reproduced from the best available copy. Available in paper copy. Printed in the United States of America. To obtain copies of this report, contact:

Westinghouse Hanford Company - Document Control Services

P.0. Box 1970, Mailstop H6-08, Richland, WA 99352

Telephone: (509) 372-2420; Fax: (509) 376-4989 
THIS PAGE INTENTIONALLY

LEFT BLANK 


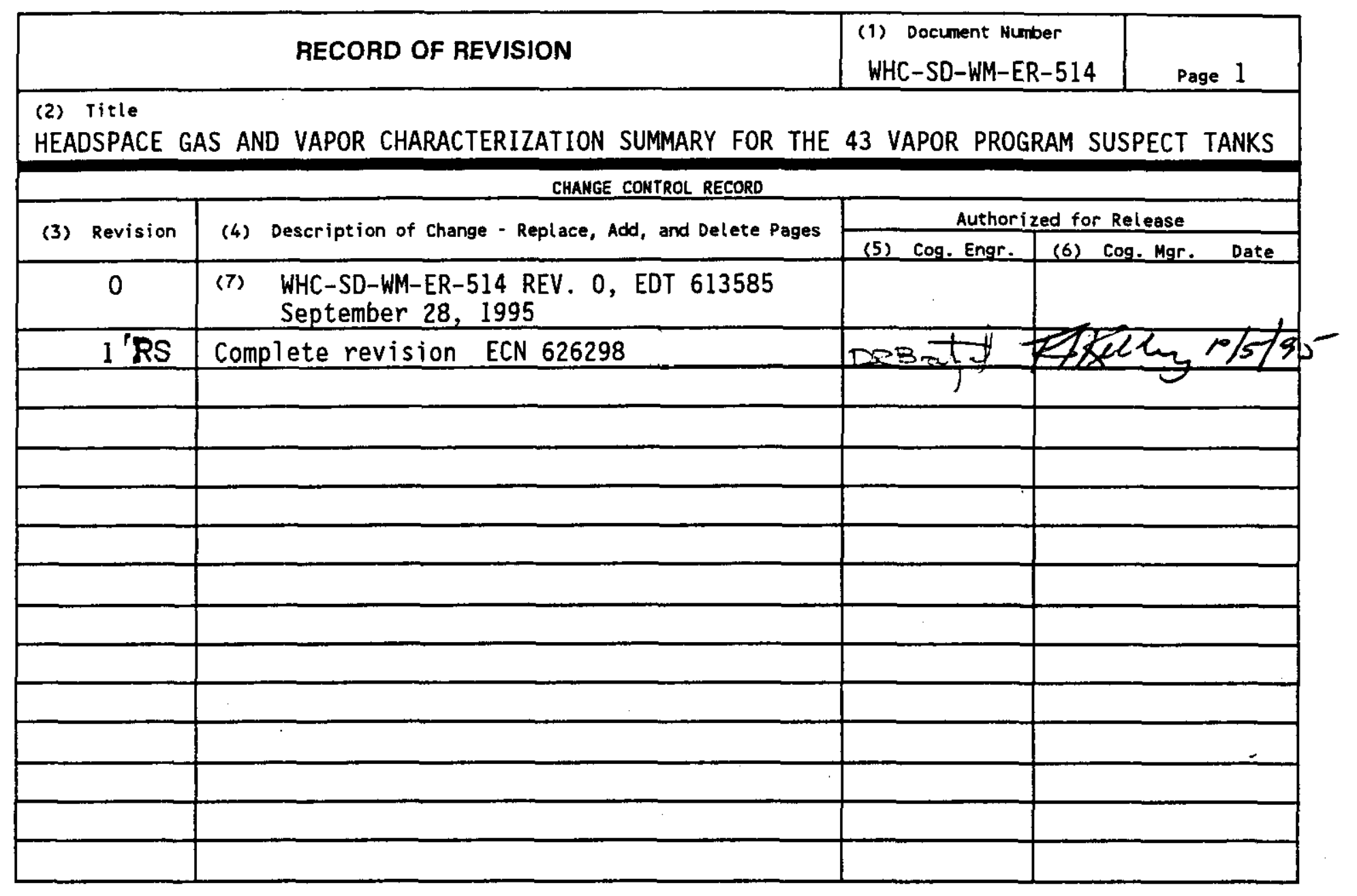


TAIS PAGE INTENTTONALLY

Mm LERT BLANK 
2. Title

HEADSPACE GAS AND VAPOR CHARACTERIZATION SUMMARY FOR THE 43 VAPOR PROGRAM SUSPECT TANKS

5. Key Words

CHARACTERIZATION OBJECTIVES, TANK HEADSPACE, SAMPLING EVENTS, INORGANIC GASES, ORGANIC VAPORS
3. Number

WHC-SD-WM-ER-514 4. Rev No.

1
6. Author

Name: D. R. BRATZEL

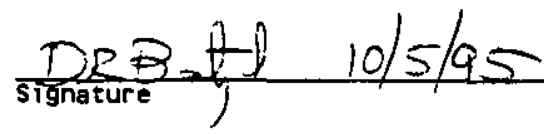

Organization/Charge Code

$75640 / \mathrm{N} 4 \mathrm{AB} 1$

\section{Abstract}

During the time period between February 1994 and September 1995, Westinghouse Hanford Company (WHC) sampled the waste-tank headspace of 43 single-shell tanks for a variety of gaseous and/or volatile and semi-volatile compounds. This report summarizes the results of analyses of those sampling activities with respect to both the Priority 1 Safety Issues and relative to the detection in the headspace of significant concentrations of target analytes relating to worker breathing space consideration as recommended by the Pacific Northwest Laboratory (PNL) Toxicology Review Panel. The information contained in the data tables was abstracted from the vapor sampling and analysis tank characterization reports. Selected results are tabulated and summarized. Sampling equipment and methods, as well as sample analyses, are briefly described. Vapor sampling of passively ventilated singleshe 11 tanks (tanks $C-105, C-106$, and SX-106 were sampled and are actively ventilated) has served to highlight or confirm tank headspace conditions associated with both priority 1 safety issues and supports source term analysis associated with protecting worker health and safety from noxious vapors.

\begin{tabular}{|l|l|}
\hline 8. & RELEASE Stamp \\
OFFICIAL RELEASE & 3 \\
BY WHiC & \\
DATE OCT 061995 \\
Sta 4
\end{tabular}


THISS PAGE INTENTIONALUY

- ILFT BLANE

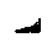




\title{
Headspace Gas and Vapor Characterization Summary for the 43 Vapor Program Suspect Tanks
}

\author{
J. L. Huckaby
}

Pacific Northwest Laboratories

\section{H. Babad}

Westinghouse Hanford Company

D. R. Bratzel

Westinghouse Hanford Company

\section{Date Published}

October 1995

Prepared for the U.S. Department of Energy

Office of Environmental Restoration and

Waste Management

(2) Westinghouse Hanford Company Richland, Washington

Management and Operetions Contractor for the

U.S. Deportment of EnergY under Contract DE.ACO6-87FL 10930 
THIS PAGE RNTENTTONALLY

\section{LIFFT BLANK}


WHC-SD-WM-ER-514 Rev. 1

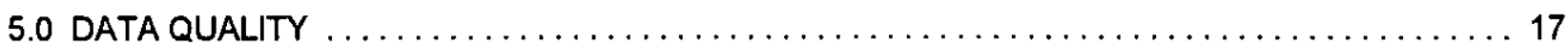

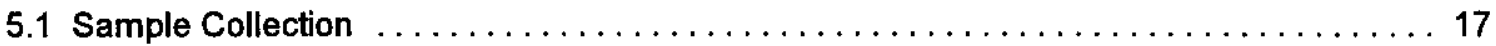

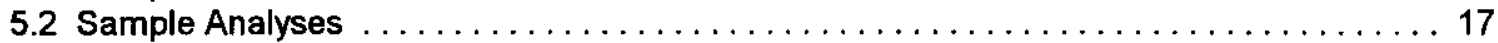

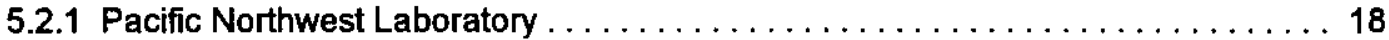

5.2 .2 Oak Ridge National Laboratory . . . . . . . . . . . . . . . . 18

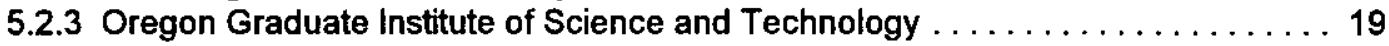

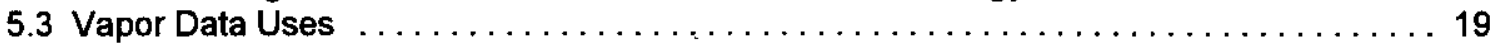

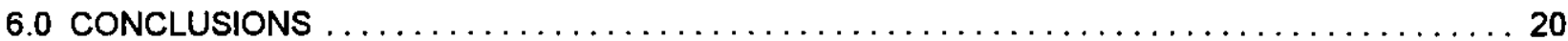

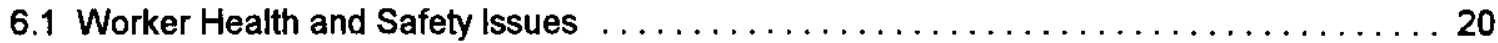

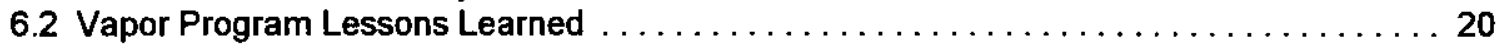

6.2.1 Problems Encountered in Early Developmental Stage ............. 20

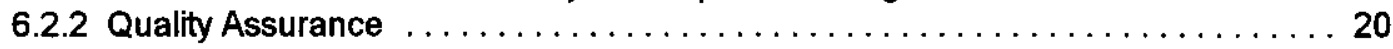

6.2.3 Vapor Data Quality Objectives and Program Direction .............. 21

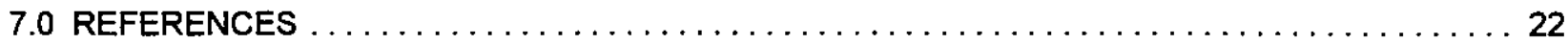

\section{TRADEMARKS}

Carbotrap C Trademark of Suppelco Company

Carbotrap Trademark of Suppelco Company

Carbosieve III Trademark of Suppelco Company 
THIS PAGE INTENTTONALLY

\section{LEFT BLANK}




\section{Headspace Gas and Vapor Characterization} Summary for the 43 Vapor Program Suspect

\section{Tanks}

J. L. Huckaby

Pacific Northwest Laboratories

H. Babad

Westinghouse Hanford Company

D. R. Bratzel

Westinghouse Hanford Company

Date Published

October 1995

Prepared for the U.S. Department of Energy

Office of Environmental Restoration and

Waste Managertent

(W) Westinghouse Hanford Company Richland. Weshingion

Niznzgement and Operasions Coniracior for the

U.S. Depariment of Enetgy under CorifeCI DE.ACOS-\&7RLiOS:O 
THES PAGE INTENTIONALLY

- ILEFT BLANE 
WHC-SD-WM-ER-514 Rev. 1

\author{
EXECUTIVE SUMMARY
}

During the time period between February 1994 and August 1995, Westinghouse Hanford Company (WHC) sampled the dome space of $\mathbf{4 3}$ single-shell tanks for a variety of organic and inorganic gases and vapors. This report summarizes the results of analyses of those sampling activities with respect to both the Hanford priority 1 safety issues and the detection in the dome space of significant concentrations of target analytes relating to worker breathing space consideration as recommended by the Pacific Northwest Laboratory Toxicology Review Panel (Mahlum et al. 1994). The information contained in the data tables was abstracted from the tank headspace gas and vapor characterization reports. Vapor sampling of passively ventilated single-shell tanks (note tanks C-104, C-105, C-106, SX-103, and SX-106 are actively ventilated) has served to highlight or confirm headspace conditions associated with both priority 1 safety issues (e.g., the presence of organic liquid wastes potentially capable of supporting combustion) and supported source term analysis associated with protecting worker health and safety from noxious vapors.

\title{
Priority 1 Safety Issues
}

Vapor sampling has been used to assess potential priority 1 safety issues, including the following:

- Flammable gas constituents (e.g., hydrogen, ammonia, methane) present at or above $25 \%$ of their lower flammability limit;

- Volatile and semivolatile organic vapors (e.g., acetone, 1-butanol, dodecane, tridecane) present at or above $25 \%$ of the mixture lower flammability limit;

- Organic waste liquids (e.g., dodecane, tridecane, tributyl phosphate) present at or near the surface of the waste and representing a potential flammability hazard; and

- Hydrogen cyanide, an unlikely product of the degradation of complex metal ferrocyanides under tank conditions. High ammonia concentrations are also associated with ferrocyanide tanks.

Table 1, entitled "Analytes Important to Safety Issue Identification", includes data from headspace measurements related to the priority 1 safety issues.

The following tanks contained constituents in sufficiently high quantities to require altering the respective programs to assure that adequate controls existed on the designated tank to assure continuation of interim safe storage.

- Flammable gas constituents: None of the tanks sampled contained concentrations of flammable gases (e.g., hydrogen, ammonia, methane) that approached $25 \%$ of their lower flammability limit.

- Volatile and semivolatile organic vapors: None of the tanks sampled contained concentrations of flammable organic vapors that approached $25 \%$ of their lower flammability limit. However, several tanks were determined to have concentrations of normal paraffinic hydrocarbons high enough to suggest that they might contain significant quantities of organic liquid waste. Tanks BX-104, BY-107, BY-108, C-101, C-102, and C-103 each had estimated total nonmethane organic carbon concentrations above $100 \mathrm{mg} / \mathrm{m}^{3}$. In the absence of definitive information on the ignition of wicked organic waste liquids, the conservative value of $100 \mathrm{mg} / \mathrm{m}^{3}$ was used as a basis for notifying the Organic Watch List Program. 


\section{WHC-SD-WM-ER-514 Rev. 1}

- Hydrogen cyanide and ammonia: As expected, none of the ferrocyanide Watch List tanks sampled for hydrogen cyanide contained any credible indications of its presence. Furthermore, none of the tanks sampled, including the ferrocyanide tanks, contained potentially flammable quantities of ammonia in their headspace. In all cases, the concentration of ammonia found was well below 25 $\%$ of the lower flammability limit.

\section{Target Analytes of Concern [Toxicology Review Panel List]}

Table 2. "Toxicology Review Panel Analytes of Concern (from Tank C-103)" contains the results of vapor analyses related to industrial health and safety.

- Ammonia - Tanks B-103, C-105, C-106, C-108, C-109, C-111, C-112, TX-105, TY-101, U-203, and U-204 were the only tanks (11 of the 43 sampled) that did not exceed the consensus exposure standard of $25 \mathrm{ppmv}$ for ammonia.

- Nitrous Oxide - Tanks BY-103, C-105, C-106, C-110, SX-103, SX-106, T-111, TX-105, U-203 and U-204 were the only tanks ( 10 of 43 ) with concentrations below the consensus exposure standard of $25 \mathrm{ppmv}$ for nitrous oxide.

- Benzene - Four tanks (BY-108, C-101, C-102, and C-103) exceeded the 0.1 ppmv consensus exposure standard for benzene in Oak Ridge National Laboratory thermal desorption trap samples.

- Other Analytes - In addition, Oak Ridge National Laboratory analysis of vapors in tank U-106 suggest the presence of trace quantities of methyl isocyanate. However, this finding could not be confirmed with SUMMA ${ }^{\mathrm{TM}, 1}$ sample analyses. Other analytes, (e.g., polychlorinated biphenyls) were occasionally tentatively identified and estimated to be at or above action limits.

In all instances WHC industrial hygiene personnel, tank farm operations, and safety programs were notified by the laboratories when action levels set in Tusler (1994) were exceeded.

1 SUMMA is a trademark of Molectrics, Inc., Cleveland, Ohio. 


\section{WHC-SD-WM-ER-514 Rev. 1}

\section{Contents}

EXECUTIVE SUMMARY $\ldots \ldots \ldots \ldots \ldots \ldots \ldots \ldots \ldots \ldots \ldots \ldots \ldots \ldots \ldots \ldots \ldots$

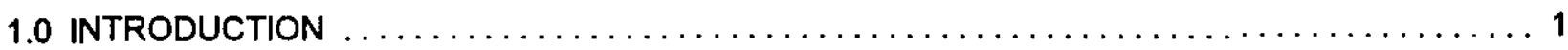

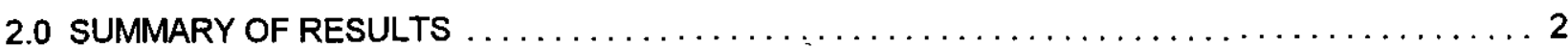

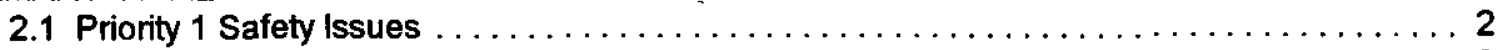

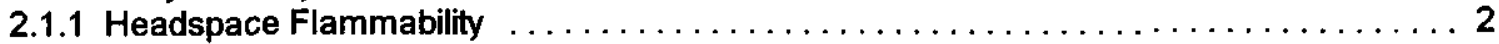

2.1.2 Volatile and Semivolatile Organic Constituents and Organic Liquid . . . . . . . . 2

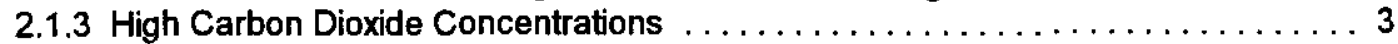

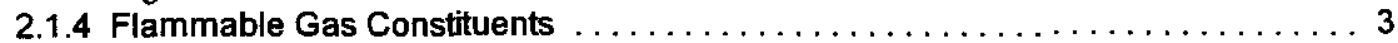

2.1.5 Ferrocyanide Degradation Products $\ldots \ldots \ldots \ldots \ldots \ldots \ldots \ldots \ldots \ldots \ldots \ldots$

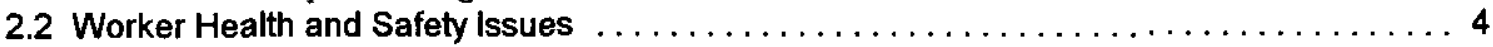

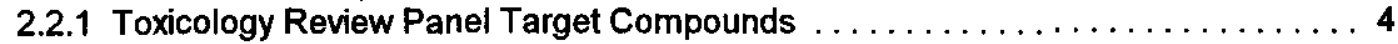

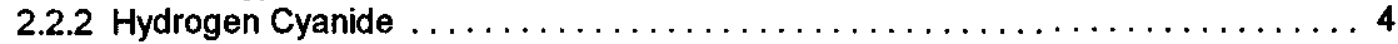

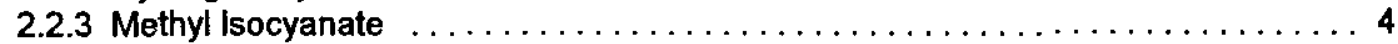

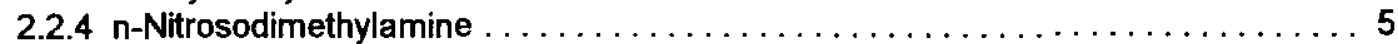

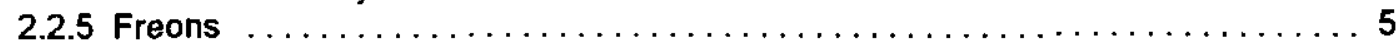

2.2.6 Other Tentatively Identified Compounds of Toxicological Concern . . . . . . . 6

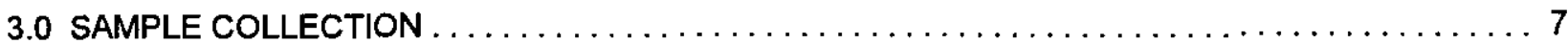

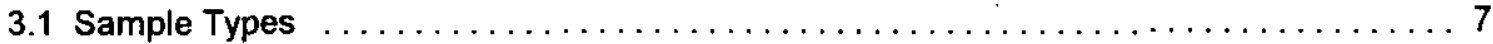

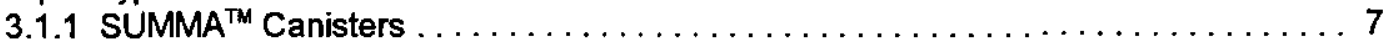

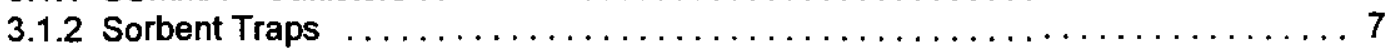

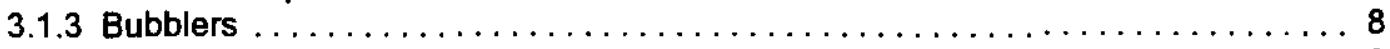

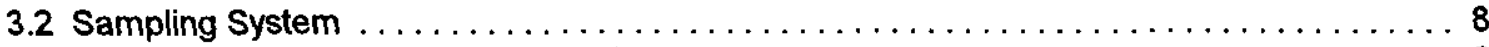

3.2 .1 Vapor Sampling System $(\mathrm{VSS}) \ldots \ldots \ldots \ldots \ldots \ldots \ldots \ldots \ldots \ldots \ldots \ldots \ldots$

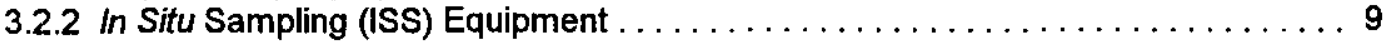

3.3 Sampling Event Description . . . . . . . . . . . . . . . . . . . . .

3.3.1 Vapor Sampling System (VSS) Sampling Events $\ldots \ldots \ldots \ldots \ldots \ldots \ldots \ldots$

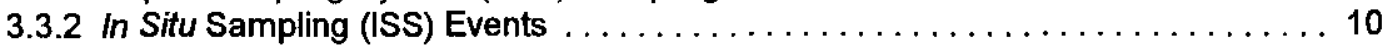

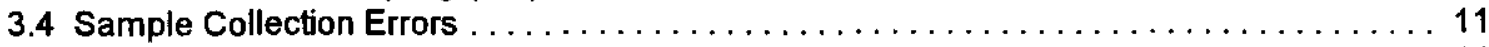

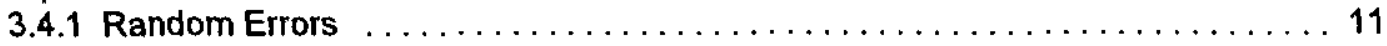

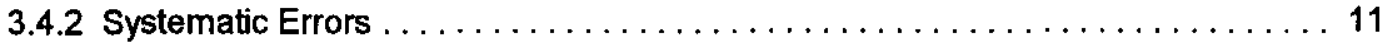

3.5 Sample Handling, Shipment, and Storage Errors $\ldots \ldots \ldots \ldots \ldots \ldots \ldots \ldots$

3.6 Comparison of ISS and VSS Sampling Methods $\ldots \ldots \ldots \ldots \ldots \ldots$

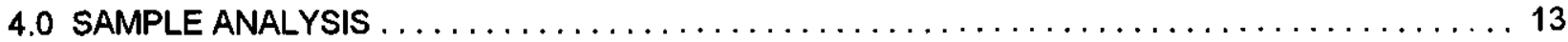

4.1 Sorbent Traps for Inorganic Vapors $\ldots \ldots \ldots \ldots \ldots \ldots \ldots \ldots \ldots \ldots \ldots \ldots$

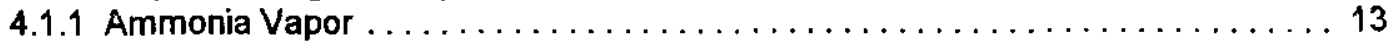

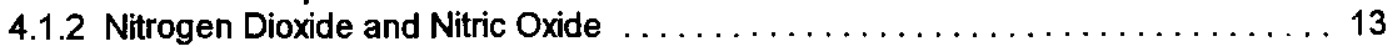

4.1.3 Water Vapor $\ldots \ldots \ldots \ldots \ldots \ldots \ldots \ldots \ldots \ldots \ldots \ldots \ldots \ldots \ldots \ldots \ldots \ldots \ldots$

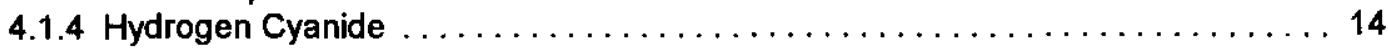

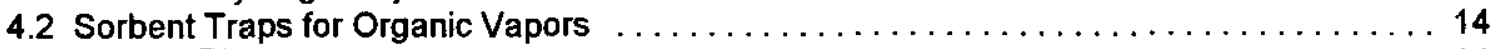

4.3 SUMMA $^{\mathrm{TM}}$ Canisters for Inorganic Gases and Vapors $\ldots \ldots \ldots \ldots \ldots \ldots \ldots \ldots$

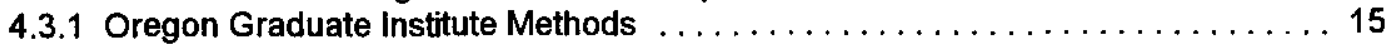

4.3.2 Pacific Northwest Laboratory Methods . . . . . . . . . . . . . . . . . . . 15

4.4 SUMMA $^{\mathrm{TM}}$ Canisters for Organic Gases and Vapors $\ldots \ldots \ldots \ldots \ldots \ldots \ldots$

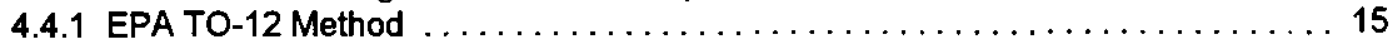

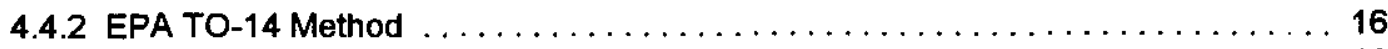

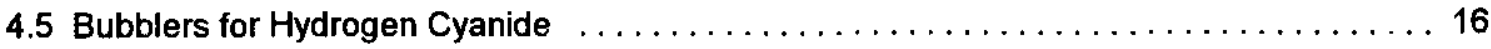


WHC-SD-WM-ER-514 Rev. 1

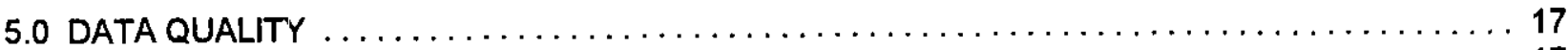

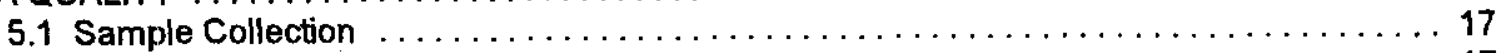

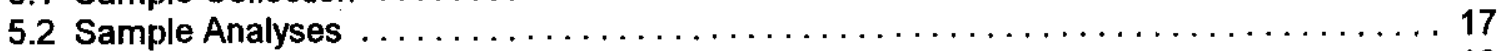

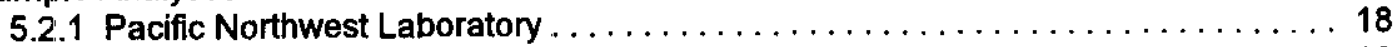

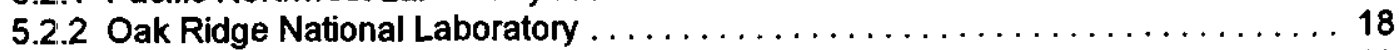

5.2.3 Oregon Graduate Institute of Science and Technology . . . . . . . . . . 19

5.3 Vapor Data Uses . . . . . . . . . . . . . . . . . . . . . . . . 19

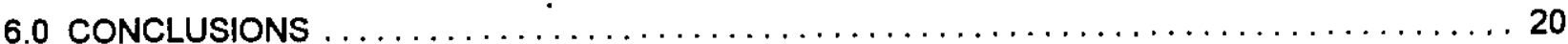

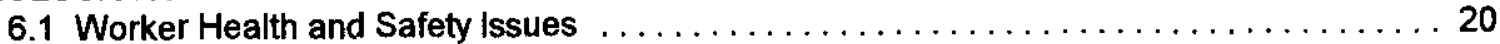

6.2 Vapor Program Lessons Learned . . . . . . . . . . . . . . . . . . . . . . . 20

6.2.1 Problems Encountered In Early Developmental Stage . . . . . . . . . . . . 20

6.2 .2 Quality Assurance . . . . . . . . . . . . . . . . . . . . . . . . . . 20

6.2.3 Vapor Data Quality Objectives and Program Direction . . . . . . . . . . . 21

7.0 REFERENCES 


\subsection{INTRODUCTION}

This report summarizes the results of selected Hanford Site high-level radioactive waste tank headspace sampling conducted between February 1994 and August 1995. Sampling equipment and methods, as well as sample analyses, are briefly described. Selected results are tabulated and summarized. Implications of the results to Priority 1 Safety lssues and to tank farm worker health and safety issues are discussed. Discussion of worker health and safety issues is based on use of the results as industrial hygiene source term characterization data, and on an assessment by the Pacific Northwest Laboratory Toxicology Review Panel (Mahlum et al. 1994).

Tanks selected for this summary report include those of the Thomas P. Grumbly Safety Initiative SI-2o, Sample and Characterize Remaining Suspect Tanks by October 1995. Specifically, all Ferrocyanide, Organic, and High Heat Watch List tanks as of May 1995 (Hanlon 1995), all non-Watch List tanks in 241-C tank farm, and tank BX-104 are discussed in this report. These 43 tanks are listed in Table 1. 


\section{WHC-SD-WM-ER-514 Rev. 1}

\subsection{SUMMARY OF RESULTS}

\subsection{Priority 1 Safety Issues}

\subsubsection{Headspace Flammability}

Characterization data indicate there are primarily 3 fuels in the tank headspaces. These are hydrogen, ammonia, and organic vapors. While these had been identified long before the current campaign to more thoroughly characterize the headspace constituents, there is now a much better understanding of their concentration on a tank-by-tank basis. It should be noted that the flammable gas program has an interest not only in characterizing the contents of the dome space for flammable components, but also for monitoring the day-by-day changes of hydrogen and ammonia concentration in the tank. This document and the associated headspace gas and vapor characterization reports only deal with data obtained by aperiodic sampling. Table 1 lists the average measured hydrogen, ammonia, and total organic vapor concentrations for each of the 43 suspect tanks.

Among the 43 tanks discussed in this report, hydrogen was observed to be highest in tank S-102, where it was measured to be $669 \mathrm{ppmv}$. Given the lower flammability limit (LFL) for hydrogen in air is about $4 \%$ by volume, the measured hydrogen concentration in tank S-102 corresponds to about $1.7 \%$ of the LFL. At this level, hydrogen is not a significant contributor to headspace flammability. As indicated in Table 1, the average concentration for the $\mathbf{2 7}$ tanks in which hydrogen was actually detected was $246 \mathrm{ppmv}$.

Ammonia was found to be highest in tank BY-108, for which the sample average concentration was 1,040 ppmv. The LFL of ammonia in air is about $15 \%$ by volume, so the ammonia in BY-108 corresponds to only about $0.7 \%$ of the LFL. Though ammonia has been detected in all the tanks that have been sampled, it is a relatively poor fuel, and has not been found at levels that present a flammability hazard. The average ammonia concentration measured in the $\mathbf{4 2}$ suspect tanks in which ammonia was above the analytical detection limit was 222 ppmv.

Tank C-103 has the highest concentration of organic vapors found to date, and the flammability of the headspace has been addressed in a special report, Tank 241-C-103 Headspace Flammability (Huckaby 1994a). The predominant organic vapors in tank C-103 (and in other tanks having high organic vapor concentrations) are from the evaporation of semivolatile organic liquids present (e.g., kerosene hydrocarbons and tributyl phosphate) in the waste. Because these pose special analytical difficulties, the total organic vapor concentration in tank $\mathrm{C}-103$ was not precisely determined. Rasmussen and Einfeld (1994) estimated the total nonmethane organic carbon (TNMOC) concentration in tank C-103 samples to be between 2,000 and $5,000 \mathrm{mg} / \mathrm{m}^{3}$. A summation of estimated individual organic vapor concentrations measured by Oak Ridge National Laboratory (ORNL) gives the value of $1,200 \mathrm{mg} / \mathrm{m}^{3}$ (Jenkins et al. 1994). Given the LFL for the semivolatile organic vapors is about $46,000 \mathrm{mg} / \mathrm{m}^{3}$ (Huckaby 1994a), the highest estimate for tank C-103 corresponds to about $11 \%$ of the LFL. While the fuel level in the tank C-103 headspace is high compared to other waste tanks, it is well below levels of concern, and is naturally limited by the tank temperature and volatility of the organic liquid. Incredible changes would have to occur within tank C-103 to raise the headspace organic fuel concentration to its LFL (e.g., waste temperatures would need to rise about $60^{\circ} \mathrm{C}$, Postma et al. 1994).

\subsubsection{Volatile and Semivolatile Organic Constituents and Organic Liquid}

Vapor sampling can provide an indication whether the dome space of a tank contains significant concentrations of volatile and semi-volatile organic constituents (e.g., dodecane, undecane, 1-butanol, acetone) above their flashpoint. Note that vapor pressure-temperature relationships for the organic constituents are used in assessing this condition. A number of tanks were identified that had sufficiently 
high concentrations of normal paraffin hydrocarbons or predecessor hydrocarbon solvents to suggest that they might contain significant quantities of phase-separated organic liquid as evidenced by the concentration of hydrocarbons in the tank headspaces. Tanks BX-104, BY-107, BY-108, C-101, C-102, and $\mathrm{C}-103$ each had estimated total nonmethane organic carbon concentrations above $100 \mathrm{mg} / \mathrm{m}^{3}$. In the absence of definitive information on the ignition of wicked organic liquid wastes, the conservative value of $100 \mathrm{mg} / \mathrm{m}^{3}$ was used as a basis for notifying the Organic Tank Safety Program.

\subsubsection{High Carbon Dioxide Concentrations}

Several tanks have been determined to have carbon dioxide concentrations higher than ambient air levels. Generally, carbon dioxide introduced by air exchange with the atmosphere is absorbed by the caustic waste liquids, and converted to carbonate in solution. For this reason, the carbon dioxide concentration measured in the tank headspaces are usually much lower than it is ambient air. Ambient air levels of carbon dioxide are typically 350 to $400 \mathrm{ppmv}$, and generally range from about 10 to $200 \mathrm{ppmv}$ in the passively ventilated tank headspaces. However, in several tanks, notably tanks C-101 and C-107, the carbon dioxide concentrations were unexpectedly high, at about $1400 \mathrm{ppmv}$ and $700 \mathrm{ppmv}$, respectively.

The apparent explanation for the observed carbon dioxide levels is that the waste liquids in these tanks contain relatively high concentrations of carbonate. Liquid from an auger sample collected in March 1995 from tank C-101 was measured to have a pH of 10.7, and an inorganic carbon concentration of $3.99 \mathrm{mg}$ of carbon/mL (Hall 1995). Using the simple equilibrium relationships between the $\mathrm{pH}$, aqueous carbonate and bicarbonate, and carbon dioxide gas, Hall (1995) calculated the carbon dioxide concentration in tank C101 should be about $23,400 \mathrm{ppmv}$. While this is apparently not an accurate prediction, it does suggest that even at relatively high pH values, the measured carbonate concentration in tank $\mathrm{C}-101$ could evolve carbon dioxide gas (rather than absorb it). The inaccuracy of the calculation could be attributed to several things, and is relatively sensitive to both $\mathrm{pH}$ and temperature (neither of which are well characterized for all parts of the tank).

\subsubsection{Flammable Gas Constituents}

None of the tanks sampled had concentrations of flammable gases (e.g., hydrogen, ammonia, methane) that approached $25 \%$ of the LFL of the flammable constituents.

\subsubsection{Ferrocyanide Degradation Products}

Hydrogen cyanide is an unlikely product of the degradation of complex metal ferrocyanides under tank conditions. High ammonia concentrations are also associated with the aging of ferrocyanide wastes (Lilga et al. 1992, 1993, 1994, 1995). As expected, none of the Ferrocyanide Watch List tanks sampled for hydrogen cyanide contained any credible indications of its presence. Furthermore, none of the tanks sampled, including the ferrocyanide tanks, contained potentially flammable quantities of ammonia in their dome space. In all cases, the concentration of ammonia found was well below $25 \%$ of the LFL. 
WHC-SD-WM-ER-514 Rev. 1

\subsection{Worker Health and Safety Issues}

\subsubsection{Toxicology Review Panel Target Compounds}

Table 2, "Toxicology Review Panel Analytes of Concern", contains the results of gas and vapor analyses related to industrial health and safety. The consensus exposure standard (CES) values listed in the header row of Table 2 are from Toxicological Evaluation of Analytes from Tank 241-C-103 (Mahlum et al. 1994). The following summarizes the results given in Table 2:

- Ammonia - Tanks B-103, C-105, C-106, C-108, C-109, C-111, C-112, TX-105, TY-101, U-203, and $U-204$ were the only tanks ( 11 of the 43 sampled) that did not exceed the CES of 25 ppmv for ammonia.

- Nitrous Oxide - Tanks BY-103, C-105, C-106, C-110, SX-103, SX-106, T-111, TX-105, U-203 and U-204 were the only tanks ( 10 of 43) with concentrations below the CES of $25 \mathrm{ppmv}$ for nitrous oxide.

- Benzene - Tanks BY-108, C-101, C-102, and C-103 exceeded the 0.1 ppmv CES for benzene in ORNL thermal desorption trap samples.

In all instances, WHC Industrial Hygiene, Tank Farm Operations, and Safety Programs were notified by the laboratories when action levels set in Tusler (1994) were exceeded.

\subsubsection{Hydrogen Cyanide}

It was proposed that hydrogen cyanide could be evolved from ferrocyanide-bearing wastes, and then transported to the breathing zone of tank farm workers by passive ventilation of the tank headspaces (Saget 1992). Saget pointed out that, although the high $\mathrm{pH}$ of the waste would normally preclude any significant liberation of hydrogen cyanide gas, literature indicated that hydrogen cyanide was liberated even by basic solutions of ferrocyanide when irradiated.

To resolve the issue of hydrogen cyanide, 10 of the Ferrocyanide Watch List tanks were sampled for hydrogen cyanide. No hydrogen cyanide was detected in any of the tanks. The 10 tanks sampled for hydrogen cyanide are indicated in Table 1 , and the method detection limit for each tank is given. These tanks were chosen among the Ferrocyanide Watch List tanks on the basis of their diverse waste conditions, and the finding of no hydrogen cyanide in these provides very strong evidence that no appreciable hydrogen cyanide concentrations exist in any of the waste tank headspaces. No further sampling for hydrogen cyanide is planned.

\subsubsection{Methyl Isocyanate}

ORNL tentatively identified methyl isocyanate (MIC) in 1 of the TST samples from the August 1994 ISS of tank U-106. Because of MIC's high toxicity, ORNL attempted to confirm or refute MIC's presence on the TST using an authentic standard of MIC, and to provide an estimate of its potential headspace concentration. ORNL did confirm the presence of the MIC on the sorbent trap, suggesting a level in the headspace of about $0.017 \mathrm{ppmv}$, but could not determine whether the MIC was on the trap due to its actual presence in the tank headspace, or to artifactual production on the trap during sample storage or analysis. Samples obtained from the March 1995 VSS sampling of tank U-106 again showed MIC present in the sorbent traps, but at an even lower level (about $0.001 \mathrm{ppmv}$ ). In these samples, the confirmation of MIC's presence was less definitive, because of analytical interferences by ethanol. Pacific Northwest Laboratory 
WHC-SD-WM-ER-514 Rev. 1

(PNL) did not observe MIC in the SUMMA ${ }^{\mathrm{TM}, 2}$ canister samples which it had analyzed from the second sampling.

While the ORNL data strongly indicate the presence of MIC in the TST samples from the headspace of tank U-106, whether the MIC detected is from the tank headspace or an artifact of the sample collection and/or analysis was not determined. Resolution of the source of MIC was not deemed to be critical, because the estimated concentration of MIC (assuming it actually came from the tank U-106 headspace) is relatively low, and without a plausible means of concentrating MIC in the workers' breathing zone, it does not pose a threat to workers in the vicinity of the tank. The National Institute for Occupational Safety and Health (NIOSH) gives an 8-hour recommended exposure limit (REL) for MIC of 0.020 ppmv, and an immediately dangerous to life and health (IDLH) level of $3.0 \mathrm{ppmv}$ (NIOSH 1995). The estimated concentration of MIC in the tank U-106 headspace (assuming it is not an artifact of sampling or analysis), is less than $1 \%$ of this IDLH level. Workers who could be directly exposed to the air, gases, and vapors emitted by tank U-106 (e.g., during intrusive work) would currently be required to use supplied air breathing equipment.

\subsection{4 n-Nitrosodirnethylamine}

ORNL tentatively identified $n$-nitrosodimethylamine (NDMA) in the headspace of tanks U-103, U-105, U106, U-107, and U-111. Authentic standards were used to establish retention times and mass spectral fragmentation patterns in confirmation studies. However, separate calibration runs for NDMA levels were not performed for all tanks. Mean headspace estimated concentrations ranged from a low of $0.04 \mathrm{mg} / \mathrm{m}^{3}$ in tank $\mathrm{U}-107$ to a high of $0.21 \mathrm{mg} / \mathrm{m}^{3}$ in tank U-103. Although NDMA is present in tobacco smoke, and is considered to be carcinogenic, NIOSH does not specify an exposure limit. However, the U.S. Occupational Safety and Health Administration (OSHA) does maintain a standard (29CFR 1910.1016) which mandates special handling precautions if the mixture contains greater than $1 \%$ NDMA. The highest mean concentration was $0.21 \mathrm{mg} / \mathrm{m}^{3}$ in tank U-103, or about $0.064 \mathrm{ppmv}$. This is equivalent to $0.0000064 \%$ of the headspace volume, so this handling standard would not apply to the tank headspace.

\subsubsection{Freons}

Halocarbons have been identified in many of the passively ventilated tank headspaces. Some of these are chlorinated solvents (commonly used in the past because they are essentially nonflammable) that were apparently placed in the waste tanks when contaminated. However, this would not explain the presence of the most commonly detected halocarbon, trichlorofluoromethane. Trichlorofluoromethane is a freon (freon 11) with a boiling point of $23^{\circ} \mathrm{C}$, and not commonly used as a cleaning solvent. The measured concentrations of trichlorofluoromethane (i.e., in the 0.005 to $2.0 \mathrm{ppmv}$ range) are relatively low, however, and are not thought to pose a risk to tank farm workers.

It has recently been proposed that the presence of trichlorofluoromethane in the waste tank headspaces may be due to its use in urethane foams that were applied to seal above-ground leak points (e.g., at concrete sluice and pump pit covers). Specifically, the bubbles in the urethane foam contain trichlorofluoromethane. A correlation between the waste tanks which have detectable quantities of trichlorofluoromethane (and/or other freons) and the tanks which were sealed with that type of urethane foam has not been performed, but the relationship is reasonable. Given the very slow air exchange rates of most passively ventilated tanks, an initial trichlorofluoromethane concentration of $100 \mathrm{ppmv}$ in a tank's concrete sluice or pump pit would produce measurable concentrations in the main tank headspace for many years.

\footnotetext{
2 SUMMA is a trademark of Molectrics, Inc., Cleveland, Ohio.
} 


\subsubsection{Other Tentatively Identified Compounds of Toxicological Concern}

In addition to the target analytes and specially noted compounds above, several compounds of potential toxicological concern have been tentatively identified. All sample analysis results are made available directly to WHC Inclustrial Hygiene for its review. The analytical laboratories are responsible for identifying compounds of potential toxicological interest, and are required to immediately notify WHC in the event any compound is measured to be at or above one-half of its IDLH (Tusler 1994). There were no tentatively identified compounds in any of the $\mathbf{4 3}$ tanks discussed in this report that exceeded this notification limit.

Several compounds have been tentatively identified in tank samples that were deemed to be of potential toxicological concern. Analytical laboratory personnel and scientists review all data, and have reported such findings to WHC Industrial Hygiene. For example, it was reported to WHC Industrial Hygiene that several polychlorinate biphenyls were tentatively identified in headspace samples from tanks TY-101, TY103, and TY-104. 
WHC-SD-WM-ER-514 Rev. 1

\subsection{SAMPLE COLLECTION}

\subsection{Sample Types}

Two primary types of sampling devices are generally used to capture (trap) vapor constituents from the dome space in the waste tanks, SUMMA ${ }^{T M}$ canisters and sorbent traps. Each method optimizes the collection of certain tank vapor constituents. SUMMA ${ }^{\mathrm{TM}}$ canisters are used to collect nonpolar gases as well as nonpolar and many polar organic vapors. Sorbent traps are used to collect organic and inorganic gases and vapors. Different sorbent traps are used for different analytes. A third type of sampling device, a liquidfilled bubbler, was also used to sample specifically for hydrogen cyanide in 2 waste tanks.

\subsubsection{SUMMA ${ }^{T M}$ Canisters}

SUMMA ${ }^{T M}$ canisters are stainless steel vessels whose internal surfaces have been prepared by the SUMMA ${ }^{T M}$ process. This process passivates active sites on the canister walls to minimize the adsorption of gases and vapors. SUMMA ${ }^{T M}$ canisters used for waste tank vapor sampling are cleaned and evacuated at an analytical laboratory before use. The evacuated canisters are filled with air from the dome space of the tank through a valve, which is then closed to seal the sample inside. SUMMA ${ }^{\mathrm{TM}}$ canisters essentially allow collection and transfer of whole-air samples from a specified dome space location to an analytical laboratory where the sample can be analyzed. SUMMA ${ }^{\mathrm{TM}}$ technology is generally accepted by analytical air chemists for ambient air, and is specifically cited in the U.S. Environmental Protection Agency (EPA) Task Order 12 (TO-12) and Task Order 14 (TO-14) methods for ambient air analysis (EPA 1988).

Despite their use as whole-air sampling devices, SUMMA ${ }^{\mathrm{TM}}$ canisters are not appropriate sampling devices for highly polar or water soluble vapors such as ammonia or acid gases (e.g., nitric oxide, nitrogen dioxide, sulfur dioxide). The tendency of such vapors and gases to be adsorbed or even chemisorbed on the canister walls affects the quantitative recovery of these analytes from SUMMA ${ }^{\mathrm{TM}}$ canisters.

\subsubsection{Sorbent Traps}

Multiple sorbent traps are used to sample organic vapors and specific inorganic gases and vapors in waste tank headspaces. Sorbent traps are typically 6 to $12-\mathrm{mm}$ diameter, 50 to $75-\mathrm{mm}$ long tubes that contain one or more beds of sorbent material, such as deactivated carbon. A known amount of sample gas is passed through the tube, which traps (by adsorption or chemisorption) virtually all of the target analyte(s). Unlike SUMMA ${ }^{\mathrm{TM}}$ canisters, sorbent traps concentrate targeted analytes by selectively removing them from the air sample. Other constituents of the air (e.g., the oxygen, nitrogen, water, etc.) are not collected. While in principle sorbent devices could be designed to sample even gases like hydrogen, it is more practical to employ a whole-air sampling device (e.g., SUMMA ${ }^{\mathrm{TM}}$ canister) for such analytes.

After sampling is complete, sorbent traps are sealed and sent to a laboratory for analysis. At the analytical laboratory, the analyte is extracted from the sorbent media, and quantitated. Given the quantity of analyte recovered and the total volume of air sampled, the concentration of analyte in the original air sample is calculated. Sample air flow rates and the duration of flow through sorbent trap sampling are specified by the analytical laboratories which supply and later analyze the sorbent traps to optimize adsorption efficiency. This information is collected and reported by WHC field staff. 
WHC-SD-WM-ER-514 Rev. 1

\subsubsection{Bubblers}

A third type of sampling device, the liquid-filled bubbler, was used to sample the tank headspaces of selected tanks for hydrogen cyanide. Bubblers are glass devices that bubble the sample air through a liquid solution. Depending on the composition of the liquid, different constituents of the sample air can be absorbed by the liquid, and trapped for future analysis. The liquid solution used to trap hydrogen cyanide, which is an acid gas, was an aqueous sodium hydroxide solution. Once absorbed by the sodium hydroxide solution, hydrogen cyanide reacts with the caustic in solution to form non-volatile sodium cyanide, which is trapped in solution for chemical analysis.

\subsection{Sampling System}

Two types of sampling apparatus were used to collect the tank headspace samples discussed in this report. The majority of data, and indeed the primary data reported in this document, were obtained using the vapor sampling system (VSS). Only a limited amount of data were obtained using in situ sampling (ISS) methods.

\subsubsection{Vapor Sampling System (VSS)}

The VSS is used to collect representative samples of the air, gases, and vapors from the waste tank headspaces. The VSS consists of a mobile laboratory, a hot-water jacketed stainless steel probe that is inserted into the tank headspace, and heated stainless steel transfer tubing that connects the mobile laboratory with the probe. Sample air is drawn from the tank headspace and through the transfer tubing and sampling manifold by an air pump. Air flow within the VSS is directed by electrically activated, pneumatically actuated valves. Instrumentation housed in the mobile laboratory provides system temperature monitoring and control, absolute and differential system pressure monitoring, mass flow metering and control, and hydrocarbon vapor monitoring. Mahon et al. (1994) describe the performance and operation of the VSS in detail.

A key feature of the VSS is its use of heated sample transfer tubing and a heated sampling manifold. Maintaining the system temperature at an electronically controlled, elevated temperature prevents vapor condensation and reduces vapor adsorption on surfaces exposed to sample air. Mahon et. al (1994) describe various tests and observations that indicate the VSS sample transfer efficiency is consistently high.

Sorbent trap samples are collected at the sorbent trap station of the sampling manifold. High-accuracy mass flow controllers are used to measure and control the flow rate of sample air through the sorbent traps. The mass flow controllers are located downstream of the sorbent trap station, and downstream of inline driers which remove water vapor from the air before it is metered. The sorbent trap station allows collection of 2 samples simultaneously, and most samples are taken in pairs.

The VSS sampling manifold also has a station for sampling air with evacuated SUMMA ${ }^{T M}$ canisters. To prevent condensation and minimize adsorption of vapors during SUMMA ${ }^{\mathrm{TM}}$ canister sampling, the connection tubing between the sampling manifold and the canister itself, as well as the mechanical valve on the SUMMA ${ }^{\mathrm{TM}}$, are heated with electrical heat tape.

The VSS is cleaned according to LO-450-80 (WHC 1994) before being used. A gas chromatograph (GC) with a flame ionization detector (FID) is used to confirm the VSS is free of hydrocarbons to its limit of detection. The GC/FID is part of the VSS, and may be used periodically throughout a sampling event to monitor organic vapor concentrations in the air being sampled. 


\subsubsection{In Situ Sampling (ISS) Equipment}

The ISS method has been a secondary method for collecting gas and vapor samples from the waste tanks. Rather than transferring the air, gases, and vapors to be sampled to a remote location, the sampling devices themselves (specifically sorbent traps) are lowered down into the headspace of the tank. This minimizes the loss of constituents by adsorption on transfer tubing walls, and circumvents the need for heated probes, heated transfer tubing and a heated sampling manifold. In recent ISS events, the sorbent traps have been attached to a small stainless steel manifold which held filters to protect the samples from contamination by radioactive particles (none of the laboratories performing sample analyses have the capability to routinely handle radioactively contaminated samples).

The ISS equipment employed to obtain samples discussed in this report consisted of a simple manifold and air pump mounted on a 2-wheel hand cart. Small bundles of about 8 sorbent traps were lowered into the tank headspace, each sorbent trap having its own 0.25 in. plastic tube connection to the sampling manifold. The ISS sampling manifold was capable of collecting 4 samples simultaneously, using needle valves to control flowrates, and rotameters to monitor flowrate.

Constituents which are not amenable to sorbent trap sampling (e.g., gases such as hydrogen, nitrous oxide, and methane) were sampled using an unheated plastic tube to transfer sample from the headspace to SUMMA ${ }^{T M}$ canisters located outside the tank. While it would be possible to lower small SUMMA ${ }^{\mathrm{TM}}$ canisters into the headspace and remotely actuate the valve to fill them, the unheated transfer tubing does not adversely affect the collection of the target gases. At low organic vapor concentrations (the usual condition of the tank headspaces), condensation of organic vapors on the unheated transfer tubing is not a concern, and only loss of constituents via absorption into condensed water or direct adsorption by the tubing walls is a problem. Loss of these constituents from the sample is minimized by purging the transfer tubing with sample air before the sample is collected. Though condensation of water vapor may occur in the unheated plastic transfer tubing, the target analytes of whole-air samples are sparingly soluble in water, and consequently would not be strongly affected.

\subsection{Sampling Event Description}

The tank headspace samples were collected at different times of day, seasons, and meteorological conditions. Though sampling has always been conducted according to written procedures, each sampling event is governed by the tank-specific requirements of the applicable tank characterization plan and/or the sampling analysis plan. For these reasons, headspace sampling events are not identical. The individual sampling event reports should be consulted for details of the individual sampling event. Brief descriptions of typical sampling event sequences for the VSS and ISS methods are described in the following subsections.

\subsubsection{Vapor Sampling System (VSS) Sampling Events}

The VSS is typically driven to the tank the day before any samples are collected, and connected to the preinstalled heated vapor probe. Heating of the transfer tubing and sampling manifold of the VSS typically begins 3 to $16 \mathrm{hrs}$ before the first samples are collected. During this warm-up period the VSS sampling manifold is maintained at a partial vacuum of about $280 \mathrm{mbar}$ ( $210 \mathrm{torr})$.

After the heated zones of the VSS have reached operating temperature, the sampling manifold is purged with ambient air typically for $30 \mathrm{~min}$ at a flowrate of more than $5 \mathrm{~L} / \mathrm{min}$. Two SUMMA ${ }^{\mathrm{TM}}$ canisters samples of ambient air are generally collected, one manually about $10 \mathrm{~m}$ upwind of the tank ventilation riser, and one using the VSS sampling manifold. The former is collected and analyzed to establish background 
WHC-SD-WM-ER-514 Rev. 1

levels of trace organic vapors, and the latter is collected and analyzed to establish the cleanliness of the sampling manifold.

A leak check of the VSS sampling manifold and transfer tubing (up to its connection to the in-tank sampling probe) is performed after ambient air samples have been collected. To perform the leak check, the sampling manifold is evacuated to $280 \mathrm{mbar}$ ( 210 torr), and the pressure of the system is monitored. Leakage resulting in less than a $3.3 \mathrm{mbar}(2.5 \mathrm{torr})$ rise.in pressure over the $15 \mathrm{~min}$ test is acceptable. Given an estimated system volume of $8.8 \mathrm{~L}$ (using a typical $9.1 \mathrm{~m}$ transfer tube), this pressure rise corresponds to a leak rate of less than $7 \mathrm{~mL} / \mathrm{min}$ at the $280 \mathrm{mbar}$ (210 torr) pressure of the leak test. During the collection of sorbent traps the system pressure is typically about 987 mbar (740 torr), which at the same leak rate would be about $2 \mathrm{~mL} / \mathrm{min}$. During collection of SUMMA ${ }^{\mathrm{TM}}$ canisters most of the sampling manifold is shut off, and the pressure of the manifold in the vicinity of the canister may drop below the pressure of the system during the leak test, but only for several seconds. Normally, the amount of air that may leak into the manifold during SUMMA ${ }^{\mathrm{TM}}$ canister filling would be expected to be very small compared to the total $6.0 \mathrm{~L}$ SUMMA ${ }^{\mathrm{TM}}$ canister sample.

After the leak test is performed, the VSS is purged with tank headspace air for $30 \mathrm{~min}$ at a flow rate greater than $5 \mathrm{~L} / \mathrm{min}$. This purge is performed to flush ambient air from the system, and saturate active adsorption sites in the collection system. Given that the volume of the heated sampling probe, transfer tubing and sampling manifold upstream of the sampling devices is typically less than $2.5 \mathrm{~L}$, this purge provides approximately 60 air turn-overs in the system upstream of the sampling ports.

\subsubsection{In Situ Sampling (ISS) Events}

ISS methods have been used to perform 3 types of headspace sampling tasks. Because the equipment and methodology has varied for each of the tasks, each is described briefly below.

The first use of the ISS method was to sample selected ferrocyanide Watch List tanks for hydrogen cyanide. The ISS approach was chosen for hydrogen cyanide sampling instead of alternate methods that relied on the transport of headspace sample air to a remote sampling device for 3 reasons. First, if unheated transfer tubing was used, water condensate within the tubing would absorb any hydrogen cyanide present in the sample air before it reached the sampling devices. (Hydrogen cyanide is quite soluble in water.) Second, because hydrogen cyanide was expected to be readily adsorbed by the stainless steel tubing of the VSS, without additional extensive testing on sample recovery to demonstrate the integrity of transfer in the VSS, it appeared to be an inappropriate method. Third, it was generally expected that the hydrogen cyanide concentration in the tank headspaces would be immeasurably low, and that any potential sample transport problems could be blamed for the lack of detectible quantities.

The ISS method was used to sample 10 ferrocyanide Watch List tanks for hydrogen cyanide, specifically, tanks BY-103, BY-104, BY-105, BY-106, C-108, C-111, C-112, TX-118, TY-101, and TY-103. Tanks C-108 and $C-111$ were sampled for hydrogen cyanide using liquid-filled bubblers in fiscal year 1993, the subsequent sampling events in fiscal year 1994 used sorbent traps. A description of the tank C-111 ISS event is given by Huckaby 1994b, and the tank C-108 ISS event was very similar. The two sampling devices provide equivalent performance.

The ISS method was also used to provide an initial measurement of semivolatile organic vapors in tank C103 to assess headspace flammability. Conducted in December 1993, the sampling event was designed to collect headspace samples of the semivolatile organic vapors and any aerosol of organic liquid that might be present (Ligotke et al. 1993, 1994). Results were used to permit certain intrusive work in tank C-103, including the collection in December 1993 of samples of the organic liquid in that tank, and the measurement of the thickness of the organic liquid layer (Huckaby 1994c). 
The ISS method was also used to collect samples to satisfy requirements of Safety Assessment for Gas Sampling All Ferrocyanide Tanks (Farley 1991). A total of 15 ferrocyanide Watch List tanks were sampled by ISS methods for this reason, specifically, tanks BY-103, BY-104, BY-105, BY-106, BY-107, BY-108, BY$111, \mathrm{C}-108, \mathrm{C}-109, \mathrm{C}-111, \mathrm{C}-112, \mathrm{TX}-118, \mathrm{TY}-101, \mathrm{TY}-103$, and TY-104. Unfortunately, during the ISS events, the sorbent trap samples lowered into the headspaces of 5 of these tanks (tanks C-108, C-109, BY$107, \mathrm{BY}-108$, and BY-111) were either contaminated by contact with the riser wall or were internally contaminated by airborne radioactive particles (the available laboratory facilities currently can not receive and analyze contaminated samples). For these 5 ISS events, only SUMMA ${ }^{T M}$ canister samples were analyzed. The requirement set by Safety Assessment for Gas Sampling All Ferrocyanide Tanks was removed in subsequent change in Ferrocyanide Program sampling needs.

In addition to the aforementioned ISS events, tanks C-101, C-107, and $U-106$ were also sampled using ISS methods. These sampling events were conducted to develop further expertise with the ISS method, and provide a basis for comparison between the ISS and VSS methods. Unfortunately, as with other early ISS events, the sorbent trap samples from tanks $\mathrm{C}-101$ and $\mathrm{C}-107$ were radiologically contaminated, and only SUMMA ${ }^{\mathrm{TM}}$ canister samples from these events were analyzed.

\subsection{Sample Collection Errors}

Sampling is subject to both random and systematic errors. Identification and correction of potential sample collection errors has involved assessments by the staff of WHC, Oregon Graduate Institute of Science and Technology (OGIST), ORNL, PNL, Northwest Instrument Systems Incorporated, and advisory and oversight groups.

\subsubsection{Random Errors}

Random errors are minimized through the use of written sampling procedures and qualified sampling personnel. Multiple headspace samples (at least 3 and as many as 6 of each type) are also collected to address random sampling errors. Analytical results for each set of similar samples are examined by the laboratories for discordant data, and the results of a single sample have occasionally been deemed invalid on the basis of a simple statistical analysis, as described in the individual laboratory reports.

\subsubsection{Systematic Errors}

The primary systematic sampling errors are those associated with sample air transport. Other systematic errors are associated with the choice of appropriate sorbent trap sample volumes, and the measurement of sorbent trap sample volumes.

Errors associated with the transfer of headspace air to the sampling devices involve the loss of analytes (by adsorption and/or absorption within the system) or the dilution of the vapor sample (due to system leaks). The VSS has been designed to eliminate condensation of water vapor and other analytes, and minimize the loss of analytes by adsorption on transfer tubing walls. In the ISS method, the transfer tubing has simply been eliminated for sorbent trap samples. Dilution of the sample air due to ambient air leaking into the system has been minimized by ensuring both the VSS and ISS equipment pass vacuum leak tests immediately before samples are collected.

Nevertheless, it is known that tributyl phosphate is adsorbed by the high efficiency particulate air (HEPA) filters used to protect sampling devices from radioactive particles (even in the VSS where the HEPA is heated and extensively purged). The partial removal of tributyl phosphate by the HEPA filters essentially invalidates any attempt to quantify the tributyl phosphate concentration in the tank headspaces. 
Errors associated with the measurement of sample air volumes directly affect calculated sorbent trap sample analyte concentrations, but have essentially no effect on SUMMA ${ }^{T M}$ canister samples. (There is no attempt or need to meter the flow of sample into a SUMMA ${ }^{T M}$ canister.) Sorbent trap sample volume measurement errors are believed to be very small (compared to analytical errors) for samples collected with the VSS, but can be significant (as large or larger than analytical errors) for samples collected using ISS methods. All flow metering equipment is periodically calibrated by the WHC Standards Laboratory.

\subsection{Sample Handling, Shipment, and Storage Errors}

Sample integrity can be adversely affected by handling and shipment errors. It has been the responsibility of the analytical laboratory that prepares and supplies the sampling devices to provide WHC Sampling and Mobile Laboratories staff with proper instructions for their handling and shipment. In addition, all tank air samples are accompanied by trip blanks, field blanks, or some other controls such as ambient air samples that senve as quality controls.

Trip blanks are sarnpling devices, identical to real samples, that accompany real samples everywhere but are not opened or exposed in the field. Trip blanks provide evidence that the samples have not been contaminated during handling and shipping. Spiked trip blanks also provide evidence that analytes have not been lost during handling or shipping. Field blanks are sampling devices that are handled in as identical manner as possible to real samples (and opened in the field), but are not used to collect samples. Field blanks provide evidence that samples are not being contaminated during shipping, handling, or by inadvertent exposure in the field.

Generally, each type of sorbent trap has at least 2 trip blanks. Sorbent trap field blanks are employed periodically. SUMMA ${ }^{\mathrm{TM}}$ canister trip blanks are not employed, because contamination of a canister sample would generally not be a function of handling or shipping conditions. SUMMA ${ }^{\mathrm{TM}}$ canisters may become contaminated if a seal or valve fails, but the fact that a trip blank canister had or had not become contaminated would have no bearing on whether the sample canisters had become contaminated. For lack of a more suitiable control, an ambient air SUMMA ${ }^{\text {TM }}$ canister is collected.

\subsection{Comparison of ISS and VSS Sampling Methods}

Despite the fact that a relatively large number of tanks have been sampled by both ISS and VSS methods, there is a paucity of comparable data. There are several reasons for this, including the fact that the ISS and VSS events have never been performed at the same time, and many ISS inorganic sorbent trap samples have been radiologically contaminated and consequently never analyzed. The only presently available comparison is that of the ISS and VSS results from tanks BY-104, BY-105, and BY-106 by Huckaby (1994d), which provides too little data from which to generalize. Additional comparative analyses between the ISS and VSS sampling methods are planned in FY 1996 to strengthen the technical basis for comparison of results. 
WHC-SD-WM-ER-514 Rev. 1

\subsection{SAMPLE ANAL.YSIS}

The waste tank headspaces may have high concentrations of gases and vapors relative to ambient air, so standard ambient air sampling and analysis methods are not always directly applicable. Assay methods applicable to the tank dome spaces were specifically developed or existing standard methods modified to meet this challenge. The specific analytical procedures used are described and/or referenced in the individual analytical laboratory reports for each waste tank.

Analytes may be "positively" or "tentatively" identified. For positive identification, the analytical instrumentation must be tested with a known chemical standard of the analyte in question, and its qualitative response (e.g., elution time) to the sample analyte must be positively correlated with its response to the standard. Sample analytes are referred to as tentatively identified when there is reasonable evidence to support the identification, but the qualitative response of the instrumentation to the analyte in question has not been established with a standard.

The amount of an analyte may be "quantitatively" determined, or simply estimated. For the analyte to be quantitatively measured, the analytical instrumentation must be calibrated with known quantities or concentrations of the analyte as a function of concentration before the sample is analyzed. Usually 3 to 5 calibration points are required. The observed response of the instrument to the unknown must be within the range of (bracketed by) the calibration curve. If not, the calibration must be extended to the region of concern. Additional calibration points may be required to satisfy standard curve linearity requirements. The concentrations of tentatively identified analytes can only be estimated. Data from the mass spectral analysis of organic analytes, for example, are frequently sufficient to tentatively identify analytes using spectral libraries. The estimation of the tentatively identified analytes' concentration is based on assumptions about such parameters as the instrument response, which result in significant errors. Before using estimated concentrations for decision making, these assumptions require evaluation.

\subsection{Sorbent Traps, for Inorganic Vapors}

Sorbent traps are used to sample ammonia, $\mathrm{NH}_{3}$; nitrogen dioxide, $\mathrm{NO}_{2}$; nitric oxide, $\mathrm{NO}$; and water vapor. These traps are supplied and then later analyzed by PNL. Sorbent trap sampling efficiency is validated by using, when possible, two sections of sorbent media in series. If sampling efficiency is high, the first section of sorbent media collects nearly all of analyte, and the second section (the breakthrough section) collects very little analyte. Analysis of breakthrough sections is discussed in the PNL analytical reports. Brief descriptions of the composition of the traps and their specific function in analysis of dome space vapors are given in the following subsections.

\subsubsection{Ammonia Vapor}

Ammonia is collected on a sulfuric acid-impregnated carbon bead medium. This sorbent medium adsorbs the ammonia and converts it to very stable and nonvolatile ammonium sulfate salt. The traps contain two sections of this sorbent material, separated by a plug of glass wool. The larger, primary section of sorbent material effectively traps all of the ammonia, while the smaller, back-up section of sorbent material is analyzed to determine whether any ammonia broke through the front bed.

\subsubsection{Nitrogen Dioxide and Nitric Oxide}

Nitrogen dioxide and nitric oxide are collected at the same time using three traps in series. The first tube in the series contains two sections (primary and back-up sections) of a triethanol amine-impregnated sorbent material known to be effective at adsorbing nitrogen dioxide. The second tube in the series contains an 
oxidizing agent that converts nitric oxide to nitrogen dioxide, and the third tube, which is identical to the first, collects the nitrogen dioxide produced in the second tube.

\subsubsection{Water Vapor}

The water vapor concentration of the headspace is established using gravimetric analysis of sorbent traps used for other analytes. Ammonia sorbent traps, for example, are prepared with a silica gel sorbent trap for water vapor connected to the outlet end. This ammonia/water vapor sorbent trap system is weighed before and after sampling, and the observed gain in weight is used to calculate the amount of water in the sample.

\subsubsection{Hydrogen Cyanide}

Both liquid-filled bubblers and sorbent traps were used to collect hydrogen cyanide samples. Though collection of these samples was different, analysis of samples by both techniques gave essentially the same results. Hydrogen cyanide trapped on sorbent traps was extracted using a caustic solution wash, and analyzed as cyanide ions by amperometric detection ion chromatography.

\subsection{Sorbent Traps for Organic Vapors}

Triple sorbent traps (TSTs) are fabricated, conditioned, and analyzed at ORNL. Sorbent trap analytical capability has been recently technology transferred from ORNL to PNL. As suggested by their name, TSTs contain three types of sorbent media, each segregated as a bed. The first bed consists of Carbotrap $\mathrm{C}^{\mathrm{TM}}$, which effectively adsorbs semivolatile organic vapors having carbon chain lengths of eight or greater. The second bed consists of Carbotrap ${ }^{\mathrm{TM}}$, which adsorbs most of the more volatile organic vapors. The third bed consists of Carbosieve $1 \mathrm{II}^{\mathrm{TM}}$, which is a molecular sieve capable of trapping virtually all highly volatile organic vapors and gases.

Maintaining an appropriate air flow in the specified direction through a TST results in a distribution of compounds among the three beds. Analytes are extracted from the TST by thermal desorption into a gas stream flowing backwards through the trap. This ensures that, for example, semivolatiles trapped on the first bed are never exposed to the second or third beds, from which they are not easily desorbed. Jenkins et al. (1994) provide detailed information on the preparation, conditioning, validation, and analysis of TSTs.

The configuration of TSTs is such that there is little doubt that all target analytes are trapped. However, the more pertinent question is whether all trapped analytes are indeed desorbed. TST analyte desorption efficiency is addressed by spiking the sorbent traps with known chemical surrogates. A surrogate, in this context, is a compound having similar or even identical chemical properties as the analyte. All TSTs (samples and blanks) are spiked with known quantities of surrogate compounds not expected to be found in the tank headspace before being used to collect samples. Desorption efficiency is calculated by comparing the amount of surrogate recovered with the amount spiked, and reported in the tank vapor analysis reports.

The accuracy of TST analyses is further addressed by using internal standards during analysis. This assures that instrument response factors are acceptable and that they do not change during multi-sample analysis.

\subsection{SUMMA ${ }^{T M}$ Canisters for Inorganic Gases and Vapors}

SUMMA ${ }^{\mathrm{TM}}$ canisters are cleaned, certified as clean using either the EPA TO-12 or TO-14 methods, and evacuated. After the canister has been filled with sample air, it is generally pressurized by the addition of 
either ultra-pure air, helium, nitrogen, or oxygen at the analyzing laboratory to facilitate sample removal. This dilutes the constituents of interest. The dilution ratio [ratio of (diluent gas + sample air)/sample air] may be determined from the change in canister pressure (the PNL method). If the diluent gas is not air, the concentration of diluent can be determined by measuring the helium concentration analytically (the OGIST method). Similarly, the volume of an aliquot taken from the canister may be measured by metering the flow (the PNL method) or measuring pressure changes (the OGIST method).

\subsubsection{Oregon Graduate Institute Methods}

SUMMA ${ }^{T M}$ canister samples were analyzed at OGIST in the past for hydrogen, carbon monoxide, methane, carbon dioxide, and nitrous oxide. The canisters were pressurized with ultra-clean helium or oxygen to facilitate sample rernoval and transfer. The pressurized canisters were allowed to equilibrate at laboratory temperature, and the dilution ratio determined by a GC with a thermal conductivity detector (TCD).

Different analytes were then measured with different instruments: Hydrogen and carbon monoxide were measured using a GC equipped with a mercuric oxide gas reduction detector; methane was measured by a GC/FID; carbon dioxide was measured by a GC/TCD; and nitrous oxide was measured by a GC equipped with an electron capture detector. Analyses were performed only after instrument calibration and calibration curve linearity was established with standards. The OGIST analytical reports provide variations and further details on these methods.

\subsubsection{Pacific Northwest Laboratory Methods}

PNL employs a single GC/TCD for analyses of hydrogen, carbon monoxide, carbon dioxide, nitrous oxide, and methane. Because the TCD relies on a difference in the thermal conductivity between the analytes and the GC carrier gas, 2 analytical runs must be made. To analyze for hydrogen, a GC run is made using nitrogen as the carrier gas. To analyze for the other analytes, a second $G C$ run is made using helium as the carrier gas. The detection limits for this method are not as low as could be provided by instruments dedicated to each analyte, but have been satisfactory to address the issues.

\subsection{SUMMA ${ }^{T M}$ Canisters for Organic Gases and Vapors}

Two types of analyses are performed to measure organic vapor concentrations in SUMMA ${ }^{\mathrm{TM}}$ canister samples, the EPA TO-12 and TO-14 methods (EPA 1988). Both methods use a cryogenically cooled loop of tubing to condense (concentrate) the nonmethane organic compounds in an aliquot of the air sample. The condensed analytes are then rapidly heated and swept into a GC with a carrier gas.

\subsubsection{EPA TO-12 Method}

In the TO-12 method, the GC performs very little chemical separation, and a FID is used to quantitatively measure the total nonmethane organic carbon (TNMOC) concentration. The TO-12 method was designed and intended for annbient air sample analysis, where TNMOC levels are relatively low, and the predominant organic vapors are volatile. Unfortunately, its accuracy and repeatability when applied to waste tank air samples decreases as the TNMOC concentration increases, and as the ratio of semivolatile to volatile vapors increases. Thus, a measured TNMOC concentration of $1000 \mu \mathrm{g} / \mathrm{m}^{3}$ is probably quite accurate and repeatable, but very high TNMOC concentrations $\left(>10^{5} \mu \mathrm{g} / \mathrm{m}^{3}\right)$ due to semivolatile organic vapors should be considered to be only an estimate. In an extreme case, the TNMOC concentration of tank 241-C-103 samples, which have high concentrations of the semivolatile normal paraffinic hydrocarbons, could only be determined to be between $2 \times 10^{6}$ and $5 \times 10^{6} \mu \mathrm{g} / \mathrm{m}^{3}$. The TO-12 method is still very useful for 2 reasons: First, it does provide an estimated tank TNMOC concentration for comparison with other tanks; and second, it allows the analytical laboratory to determine proper sample aliquot size for optimum TO-14 analyses. 


\subsubsection{EPA TO-14 Method}

In the TO-14 method, a capillary column is used to optimize chemical separation within the GC, and a mass spectrometer (MS) detector is used to identify and quantitate the analytes as they elute. Though the TO-14 method, as published by EPA, has a target list of only about $\mathbf{4 0}$ specifically named analytes, the method can be applied to identify and quantitate other analytes as well. However, most TO-14 method analyses performed to date on tank samples have been positively identified and quantitated only for the TO-14 analytes. Other analytes have only been tentatively identified and their concentrations have been estimated.

\subsection{Bubblers for Hydrogen Cyanide}

Liquid-filled bubblers were used to collect hydrogen cyanide samples in tanks C-108 and C-111. Hydrogen cyanide trapped by the caustic liquid-filled impingers was analyzed directly as cyanide ions by amperometric detection ion chromatography. Lerner and Pool (1994) describe the preparation and analysis of the hydrogen cyanide bubblers. 
WHC-SD-WM-ER-514 Rev. 1

\subsection{DATA QUALITY}

The tank headspace characterization data summarized in this report were obtained over a 19 month period, during which technical and quality assurance (QA) improvements were made to sample collection and analysis methods. Data from the initial sampling events clearly have both technical and quality assurance deficiencies, having been conducted under R\&D quality protocols (e.g., "best laboratory practices). Though much has been done to convert the program to a routine production mode, even the most recent vapor data require qualification for end-user decision making purposes. This section discusses data quality in terms of its technical validity and quality assurance measures.

\subsection{Sample Collection}

Most of the data presented below were obtained from samples collected using the vapor sampling system (VSS). Tank headspace samples collected using the VSS are generally believed to be representative of the headspace. The basic sample collection method of the VSS has not changed significantly since its first use in January 1994. However, from the first use of the VSS until issuance of an approved operating procedure on July 28, 1994, tank headspace vapor samples were collected under QA guidelines for developmental work.

Specific procedural errors are known to have occurred during the collection of samples from the first 3 tanks sampled, specifically tanks $C-104, C-105$, and C-106. These procedural errors resulted in inaccurately measured sorbent trap sample volumes, but should not have adversely affected SUMMA ${ }^{\mathrm{TM}}$ canister samples. The error associated with sorbent trap volumes for these 3 tanks has been estimated by WHC Field Analytical Services and is discussed in the individual headspace characterization reports.

Some of the data presented were obtained from samples collected using in situ sampling (ISS) methods. The ISS methodology allows one to lower the sorbent tubes directly into the tank dome space. Because limitations of the ISS equipment reduced the accuracy of sorbent trap sample results, the technical validity of sorbent trap sample results have not been treated as of equal quality to those from the VSS. Despite the different techniques, the SUMMA ${ }^{T M}$ canister sample results from the ISS sample collection method are quite comparable to those from the VSS, for the relatively few tanks where both techniques were used. Similar results were obtained between the two methods for the permanent gases. While ISS and VSS SUMMA ${ }^{\mathrm{TM}}$ canister sample results are generally comparable, the ISS samples have had greater quality assurance related problems associated with them. For example, chain of custody information is often incomplete for the ISS samples. These concerns are not inherent in the sampling methods used, only in our past implementation of quality programs for those techniques. Furthermore, the quality problems encountered in going from an R\&D to a production mode did not appear to harm the ability to identify and quantify dome space constituents, only our ability to rigorously defend their quality.

\subsection{Sample Analyses}

Three laboratories prepared and analyzed tank headspace sampies. These were ORNL, OGIST, and PNL. In addition, Sandia National Laboratory was associated with the preparation of the OGIST analytical reports, and was contractually responsible for all OGIST data.

Because the tank headspaces contain a wide variety of constituents present at widely varying (and relatively unknown) concentrations, standard air sampling and analysis methods could not generally be applied without modifications. In particular, the presence of high ammonia and moisture content in many tanks provided a challenge to both sample collection and analysis. 
The first preliminary (practice) samples obtained with the VSS were collected from tank C-103 on January 25-28, 1994. These samples contained so much semivolatile organic material that multiple dilutions and repeated application of the best available method for total organic vapor measurement provided only the rough estimate of 2,000 to $5,000 \mathrm{mg} / \mathrm{m}^{3}$ of organic material. By contrast, ambient air methods could be applied almost directly to the next tank sampled, tank C-106, which was sampled on February 15, 1994. In tank C-106 samples the total organic vapor concentration was measured to be $0.41 \mathrm{mg} / \mathrm{m}^{3}$ with a standard deviation of only $0.03 \mathrm{mg} / \mathrm{m}^{3}$. Given this situation, the only viable way to develop analytical methods for tank headspace characterization was to collect samples from a variety of tanks, and allow the laboratories to develop the appropriate methodologies and expertise to contend with the various sample diversity problems. A consequence of this approach has been that data for the initial set of tanks sampled are not equivalent, by either technical or quality assurance measures, to more recently sampled tanks.

Historically, the time and resources needed to develop analytical methods to characterize tank $\mathrm{C}-103$, which was the subject of a June 30,1994 DOE Safety Initiative, was underestimated. Emphasis on the technical validity and defensibility of the tank $\mathrm{C}-103$ data overshadowed formal quality assurance considerations, as well as the planned transition of the dome space vapor sampling program from a developmental mode to a production mode. The planned transfer of all analytical technologies to PNL was delayed until the PNL QA program could be brought from "best laboratory practices" to meet vapor program requirements (i.e., PNL impact level II). Schedule and milestone considerations required that the use of ORNL and OGIST was extended to meet DOE objectives for fiscal year 1994. The ORNL continued to prepare and analyze organic vapor sorbent traps in fiscal year 1995. The OGIST, which had been the primary laboratory for adapting SUMMA ${ }^{\mathrm{TM}}$ technology to characterize the waste tank headspace samples, continued to perform limited analyses, despite recognized QA program deficiencies, until analytical capability and capacity at PNL could replace the need for the OGIST analytical capability.

\subsubsection{Pacific Northwest Laboratory}

The PNL conversion from "best laboratory practices" to impact level 2 was first applied to sample preparation. All PINL samples collected by WHC after October 1, 1994 met PNL QA impact level 2 requirements. Unfortunately, the conversion of analytical procedures to QA impact level 2 and instrument difficulties at PNL resulted in a backlog of SUMMA ${ }^{T M}$ samples, and many SUMMA ${ }^{T M}$ samples were not analyzed by PNL within the administratively imposed 60-day sample holding time. A summary of sample collection and PNL. analysis dates, with calculated holding times has been given by Ligotke (1995). As no holding time study has been performed to address the stability of compounds of interest in SUMMA ${ }^{\text {TM }}$ canisters, the impact of extended storage on the results is indeterminate. However, most identified compounds in the SUMMA ${ }^{T M}$ samples would be expected to be stable over the storage time periods. The reported results are most likely minimally affected by the analysis delays.

A QA audit by WHC of PNL on January 30 through February 3, 1995, identified 3 observations and 6 concerns (Huggins 1995a), but the PNL QA program was essentially deemed satisfactory. Corrective actions were implemented to resolve the QA observations and concerns. A follow-up QA assessment was recently conducted (Huggins 1995b) and provided closure of all previously identified QA observations and concerns. However, with the recent technology transfer of sorbent trap analytical technology from ORNL to PNL, 5 new observations and one concern were identified relating to the new analytical workscope. It is currently planned that PNL will provide all routine vapor analytical capability in FY 1996 under the provision of an approved QA program.

\subsubsection{Oak Ridge National Laboratory}

Although an informal QA review of the ORNL vapor activity was conducted in August 1994, the first formal QA assessment was conducted in June 1995 (Weber 1995). All corrective actions have been completed 
WHC-SD-WM-ER-514 Rev. 1

by the ORNL to address the identified findings and concerns. A follow-up QA assessment is planned for September 1995 to ensure all previously identified QA issues have been resolved.

Although sorbent trap analytical capability was recently transferred to PNL to perform all routine analytical workscope, it is currently planned that ORNL will provide back-up analytical capability to PNL in FY 1996. This back-up analytical capability will also include performing a sub-set of duplicate analyses for QA comparison to PNL. results.

\subsubsection{Oregon Graduate Institute of Science and Technology}

The intended role of OGIST was to help the WHC vapor program select and develop methods to characterize the waste tank headspaces. OGIST was funded via Sandia National Laboratory, which was contractually responsible for all OGIST work.

Although an informal QA assessment was performed at OGIST in October, 1993, it was never intended to serve in a production role for the program. Tank $\mathrm{C}-103$ was the only tank which OGIST was to perform final analyses. Samples from other waste tanks were sent to OGIST (e.g., BX-104, BY-104, C-108, C-110, and TX-118) before tank $C-103$ was sampled using the VSS because OGIST needed tank air samples to test analytical modifications. OGIST continued to analyze samples after tank $\mathrm{C}-103$ had been characterized because it was the only laboratory capable of providing and analyzing SUMMA ${ }^{\mathrm{TM}}$ canister samples for the vapor program in the last quarter of fiscal year 1994. No funds were provided for continued use of OGIST in fiscal year 1995, and no tank samples collected after September 30, 1994 were sent to OGIST.

\subsection{Vapor Data Uses}

End-user decision criteria for vapor data obtained from sampling the headspace of waste tanks are defined in the Data Quality Objectives for Generic In-Tank Health and Safety Vapor Issue Resolution (Osborne et al. 1995) and the Rotary Core Sampling Data Quality Objective (Price 1994). Although the initial mission of the WHC vapor program was more limited, tank headspace gas and vapor characterization data are used to identify potentially hazardous waste storage conditions, as an element of the worker health and safety assurance strategy, and for environmental protection regulatory compliance purposes.

The presence of flammable constituents in the vapors of Hanford waste tanks is a safety question that must be resolved prior to conducting any type of intrusive sampling, stabilization, or remedial activities in or around the tanks. This issue addresses the flammability of the headspace of a tank.

The major worker health and safety issue which must be resolved is whether any compounds of toxicological significance may be present in the tanks at such a level that industrial health group may require notification of further actions to protect worker health and safety around the tank area(s) in order that work can be performed in a safe manner.

The Rotary Core Sampling DQO provides the environmental air permitting data quality criteria and performance specifications for vapor sampling for waste tank core sampling using the rotary mode core sampling system. 
WHC-SD-WM-ER-514 Rev. 1

\subsection{CONCLUSIONS}

\subsection{Worker Health and Safety Issues}

Vapor sampling of passively ventilated, single-shell tanks (note tanks C-104, C-105, C-106, SX-103, and SX-106 are actively ventilated) has served to highlight or confirm dome space conditions associated with both Priority 1 safely issues (e.g., identified the presence of phase-separated organic solvents potentially capable of supporting combustion) and supports source term analysis associated with protecting worker health and safety from noxious vapors.

\subsection{Vapor Program Lessons Learned}

The following are primary lessons learned from the inception of the vapor program. Lessons learned primarily include (I) transition from the developmental nature of the program from its infancy to a routine production mode, and (ii) Quality Assurance (QA) issues associated with laboratory analysis. In addition, considerable data exist from the vapor characterization of the headspace of $\mathbf{4 3}$ tanks to refine current Data Quality Objective (DQO) decision criteria and programmatic direction. Primary lessons learned are briefly described in conjunction with actions performed to improve the program. Specific issues associated with each sampling event are described in detail in the characterization reports as well as further discussed in this summary document.

\subsubsection{Problems Encountered In Early Developmental Stage}

Sampling and analysis activities performed in the early developmental stages of the program did not fully recognize the techinical difficulties to be encountered. Examples of these difficulties included inaccurate sorbent trap volumes, maintaining sample chain-of-custody, and widely varying and unknown concentrations of headspace constituents. These difficulties resulted in a larger error tolerance associated with early vapor results as compared to results obtained after expertise was gained in both sampling and laboratory analysis activities. Additional expertise was gained primarily from the characterization of a variety of tanks to allow both sampling and laboratory activities to develop the appropriate methodologies and expertise to contend with the various encountered problems.

\subsubsection{Quality Assurance}

Quality Assurance (QA) has been a graded approach over the lifetime of the vapor program due to the early technical developmental nature of the sampling and analytical methodology. As vapor methodology was developed and additional expertise was gained, additional QA requirements were defined to transition the program to a "routine production" mode. This graded approach to QA has resulted in the requirement to appropriately qualify and caveat all vapor data produced to date for end-user decision making purposes.

In conjunction with a graded approach to QA over the lifetime of the program, all analytical laboratories performing vapor analyses have had noted QA deficiencies and issues in meeting the prescribed QA requirements. These deficiencies, however, were primarily associated with $Q A$ documentation in meeting the defined QA requirements and have not affected the technical validity or use of the vapor data. All future vapor analytical workscope will be performed to approved QA programs or will require qualification of the data pending resolution of noted $Q A$ issues and/or deficiencies. Both sampling and laboratory functions continue to progress in the direction of 'routine' operations primarily to strengthen QA control and oversight. 


\section{WHC-SD-WM-ER-514 Rev. 1}

\subsubsection{Vapor Data Quality Objectives and Program Direction}

The Data Quality Objective (DQO) process is recognized as being an iterative process. Based upon the completion of the characterization of the headspace of 43 tanks, considerable vapor data exist to evaluate future DQO and programmatic direction. Vapor sampling of the tank source-term headspace has been instrumental to guide the TWRS Safety industrial health worker monitoring program in the immediate tank farm worker zone. A comparative analysis of source-term vapor data to data obtained from the industrial health monitoring program is being performed to define future toxicological and worker health requirements. In addition, resolution of Safety Program issues (e.g., flammability and organic issues) are continuing to be refined which may result in changing requirements for vapor sampling of the tank headspace. A technical basis to refine DQO decision criteria and programmatic needs is currently being developed based on these evolving changes. 
WHC-SD-WM-ER-514 Rev. 1

\subsection{REFERENCES}

29 CFR 1910.1016, 1992, "N-Nitrosodimethylamine", Code of Federal Regulations.

EPA 1988, Compendium of Methods for the Determination of Toxic Organic Compounds in Ambient Air, PB90-127374, U.S. Environmental Protection Agency, Washington, D.C.

Farley, W. G., 1991, Safety Assessment for Gas Sampling All Ferrocyanide Tanks, WHC-SD-WM-SAD-009, Rev. 2, Westinghouse Hanford Company, Richland, Washington.

Hall, B.W., 1995, Tank Characterization Report for Single-Shell Tank 241-C-101, Rev.0, Westinghouse Hanford Company, Richland, Washington.

Hanlon, B. M., 1995, Waste Tank Summary Report for Month Ending May 31, 1995, WHC-EP-0182-86, Westinghouse Harıford Company, Richland, Washington.

Huckaby, J. L., 1994a, Tank 241-C-103 Headspace Flammability, WHC-EP-0734 Rev. 1, Westinghouse Hanford Company, Richland, Washington.

Huckaby, J. L., 1994b, Tank 241-C-111 Headspace Gas and Vapor Sample Results, August 1993 Samples, WHC-SD-WM-TP-254 Rev. 0, Westinghouse Hanford Company, Richland, Washington.

Huckaby, J. L., 1994c, Vapor Characterization of Tank 241-C-103, WHC-EP-0780 Rev. 0, Westinghouse Hanford Company, Richland, Washington.

Huckaby, J. L., 1994d, Vapor Sampling System (VSS) and In Situ Sampling (ISS) Method Comparison, WHC-SD-WM-RPT-101 Rev. 0, Westinghouse Hanford Company, Richland, Washington.

Huggins, S.L., 1995a, Westinghouse Hanford Company's Assessment Number AR95-001 - PNL Laboratories, 9551457, Westinghouse Hanford Company, Richland, Washington.

Huggins, S.L., 1995b, Westinghouse Hanford Company's Assessment Number AR95-007 - Pacific Northwest Laboratory's Vapor Analytical Laboratory, 9554892, Westinghouse Hanford Company, Richland, Washington.

Jenkins, R. A., A. B. Dindal, C. E. Higgins, C. Y. Ma, J. T. Skeen, and R. R. Smith, 1994, Analysis of Tank 241-C-103 Headspace Components from Sampling Job 7B, Oak Ridge National Laboratory, Oak Ridge, Tennessee.

Lerner, B. D. and K. H. Pool, 1994, Waste Tank Safety Program Annual Status Report for FY 1993 Task 4: Innorganic Chemistry, PNL-8979-4 UC-601 UC-606 UC-607, Pacific Northwest Laboratory, Richland, Washington.

Ligotke, M. W., 1995, PNL Vapor Project Analytical Holding Times, (Letter to D. R. Bratzel, September 23,1995) Pacific Northwest Laboratory, Richland, Washington.

Ligotke, M. W., T. R. Clauss, J. L. Huckaby, G. W. Dennis, R. B. Lucke, and S. C. Goheen, 1993, Aerosol and Vapor Characterization of Tank 241-C-103: Flammability Assessment Sampling System, and Method Validation, PNL-8875 UC-606, Pacific Northwest Laboratory, Richland, Washington. 
WHC-SD-WM-ER-514 Rev. 1

Ligotke, M. W., T. R. Clauss, J. S. Fruchter, R. B. Lucke, G. W. Dennis, G. M. Mong, R. E. Hohimer, M. McCulloch, M. T. Dana, and S. C. Goheen, 1994, Aerosol and Vapor Characterization of Tank 241-C-103: Data Report for In-Tank OVS Samples Obtained 12/02/93, PNL-9368 UC-606, Pacific Northwest Laboratory, Richland, Washington.

Lilga, M. A., M. R. L.umetta, and G. F. Schiefelbein, 1993, Ferrocyanide Safety Project, Task 3, Aginst Studies FY 1993 Annual Report, PNL-8888, UC-721, Pacific Northwest Laboratory, Richland, Washington.

Lilga, M. A., M. R. L.umetta, W. F. Riemath, R. A. Romine, and G. F. Schiefelbeing, 1992, Ferrocyanide Safety Project, Subtask 3.4, Aging Studies FY 1992 Annual Report, PNL-8387, UC-721, Pacific Northwest Laboratory, Richland, Washington.

Lilga, M. A., E. V. Anderson, M. R. Lumetta, and G. F. Schiefelbein, 1994, Ferrocyanide Safety Project, Task 3: Ferrocyanide Aging Studies - FY 1994 Annual Report, PNL-10126, Pacific Northwest Laboratory, Richland, Washington.

Lilga, M. A., E. V. Anderson, R. T. Hallen, M. O. Hogan, T. L. Huber, G. L. Jones, D. J. Kowalski, M. R. Lumetta, G. F. Schiefelbein, and M. R. Telander, 1995, Ferrocyanide Safety Project, Ferrocyanide Aging Studies FY 1995 Annual Report, PNL-10713, Pacific Northwest Laboratory, Richland, Washington.

Mahon, R. D., C. M. Jones, and M. S. Story, 1994, Evaluation of the Capabilities and Use of the Vapor Sampling System for Tank Headspace Sampling and Characterization, WHC-SD-WM-RPT-094 Rev. 0, Westinghouse Hanford Company, Richland, Washington.

Mahlum, D. D., J. Y. Young, and R. E. Weller, 1994, Toxicologic Evaluation of Analytes from Tank 241-C103, PNL-10189, Pacific Northwest Laboratory, Richland, Washington.

NIOSH 1995, NIOSH Pocket Guide to Chemical Hazards, U.S. Department of Health and Human Resources, National Institute for Occupational Safety and Health, Cincinnati, Ohio.

Osborne, J.W., J.L. Huckaby, and E.R. Hewitt, 1995, Data Quality Objectives for Generic In-Tank Health and Safety Vapor lssue Resolution, WHC-SD-WM-DQO-002, Rev.1, Westinghouse Hanford Company, Richland, Washington.

Postma, A. K., D. B. Bechtold, G. L. Borsheim, J. M. Grigsby, R. L. Guthrie, M. Kummerer, M. G. Plys, and D. A. Turner, 1994, Safety Analysis of Exothermic Reaction Hazards Associated With the Organic Liquid Layer in Tank 241-C-103, WHC-SD-WM-SARR-001 Rev. 0, Westinghouse Hanford Company, Richland, Washington.

Price, D.N., 1994, Rotary Sampling Core Vapor Sampling Data Quality Objective, WHC-SD-WM-SP-003, Rev.0, Westinghouse Hanford Company, Richland, Washington.

Rasmussen, R. A., and W. Einfeld, 1994, Hanford Tank 103-C Analyses and Method Validation Development Phase, SAND94-1807, Sandia National Laboratories, Albuquerque, New Mexico.

Saget, R.P., 1992, Hydrogen Cyanide Off-Gassing from Ferrocyanide Waste Tanks (Letter 9200668 to president Westinghouse Hanford Company, January 29) Department of Energy, Richland Operations Office, Richland, Washington.

Tusler, L. A., 1994, Waste Tank Characterization Sampling Limits, WHC-SD-WM-TI-651, Westinghouse Hanford Company, Richland, Washington. 
WHC-SD-WM-ER-514 Rev. 1

Weber, J., 1995, Transmittal of TWRS Quality Assurance Assessment TWRSQA-95-0012, Tank Vapor Characterization, Oak Ridge National Laboratories, 38200-95-027, Westinghouse Hanford Company, Richland, Washington.

WHC, 1994, Collection of SUMMA Canister and Sorbent Tube Samples Using the Developmental Mobile Laboratory (DML1), LO-080-450 Rev. 0, Westinghouse Hanford Company, Richland, Washington. 
WHC-SD-WM-ER-514 Rev. 1

TABLE 1. Analytes Important to Safety Issue Identification'

\begin{tabular}{|c|c|c|c|c|c|c|c|c|c|}
\hline \multicolumn{3}{|c|}{ Analyte } & Ammonia & Hydrogen & $\begin{array}{l}\text { Nitrous } \\
\text { Oxide }\end{array}$ & $\begin{array}{l}\text { Nitric } \\
\text { Oxide }\end{array}$ & $\begin{array}{c}\text { Nitrogen } \\
\text { Dioxide }\end{array}$ & $\begin{array}{c}\text { Hydrogen } \\
\text { Cyanide }\end{array}$ & $\begin{array}{l}\text { Water } \\
\text { Vapor }\end{array}$ \\
\hline \multicolumn{3}{|c|}{ Units $^{2}$} & ppmv & ppmv & ppmv & ppmv & ppmv & ppmv & $\mathrm{mg} / \mathrm{L}$ \\
\hline \multicolumn{3}{|c|}{ Action Level ${ }^{3,4}$} & 30000 & $8000^{\circ}$ & N/A & $N / A$ & N/A & $\mathrm{N} / \mathrm{A}$ & N/A \\
\hline Tanks & $\begin{array}{l}\text { Watch } \\
\text { List }^{5}\end{array}$ & $\operatorname{Lab}^{6,7}$ & & & & & & & \\
\hline \multirow[t]{3}{*}{ A-101 } & $O \& H$ & PNL SUMMA ${ }^{\mathrm{TM}}$ & & 758 & 218 & & & & \\
\hline & & PNL Sorbent & 754 & & & $<0.09$ & $<0.01$ & & 22.3 \\
\hline & & ORNL TST & & & & & & & \\
\hline \multirow[t]{3}{*}{$A X-102$} & 0 & PNL SUMMA ${ }^{T M}$ & & $<99$ & 50 & & & & \\
\hline & & PNL Sorbent & 34 & & & 0.18 & $<0.08$ & & 11.9 \\
\hline & & ORNL TST & & & & & & & \\
\hline \multirow[t]{2}{*}{ B-103 } & 0 & PNL & 8.8 & $<99$ & 77.5 & 0.46 & $<0.02$ & & 9.9 \\
\hline & & ORNL & & & & & & & \\
\hline \multirow[t]{2}{*}{ BX-104 } & & PNL & 235 & $<94$ & 143 & 0.3 & $<0.03$ & & 5.9 \\
\hline & & ORNL & & & & & & & \\
\hline \multirow[t]{3}{*}{ BY-103 } & $F$ & PNL & 26 & $<98.6$ & 17 & $<0.09$ & $<0.02$ & $<0.005$ & 11.6 \\
\hline & & ORNL & & & & & & & \\
\hline & & OGIST & & 21.4 & 16.6 & & & & \\
\hline \multirow[t]{3}{*}{ BY-104 } & $\mathbf{F}$ & PNL & 248 & & & 0.29 & $<0.07$ & $<0.005$ & 14.1 \\
\hline & & ORNL & & & & & & & \\
\hline & & OGIST & & 295 & 201 & & & & \\
\hline \multirow[t]{3}{*}{$B Y-105$} & $F$ & PNL & 43 & & & 0.1 & $<0.02$ & $<0.005$ & 14.9 \\
\hline & & ORNL & & & & & & & \\
\hline & & OGIST & & 47.9 & 49.5 & & & & \\
\hline \multirow[t]{3}{*}{$B Y-106$} & $\mathbf{F}$ & PNL & 74 & & & 0.13 & 0.05 & $<0.01$ & 14.7 \\
\hline & & ORNL & & & & & & & \\
\hline & & OGIST & & 45.5 & 70.6 & & & & \\
\hline \multirow[t]{3}{*}{ BY -107} & $\mathbf{F}$ & PNL & 972 & & & 0.13 & $<0.02$ & & 13 \\
\hline & & ORNL & & & & & & & \\
\hline & & OGIST & & 267 & 621 & & & & \\
\hline
\end{tabular}


WHC-SD-WM-ER-514 Rev. 1

\begin{tabular}{|c|c|c|c|c|c|c|c|c|c|}
\hline \multicolumn{3}{|c|}{ Anallyte } & Ammonia & Hydrogen & $\begin{array}{c}\text { Nitrous } \\
\text { Oxide }\end{array}$ & $\begin{array}{l}\text { Nitric } \\
\text { Oxide }\end{array}$ & $\begin{array}{c}\text { Nitrogen } \\
\text { Dioxide }\end{array}$ & $\begin{array}{l}\text { Hydrogen } \\
\text { Cyanide }\end{array}$ & $\begin{array}{l}\text { Water } \\
\text { Vapor }\end{array}$ \\
\hline \multicolumn{3}{|c|}{ Units ${ }^{2}$} & ppmv & ppmv & ppmv & ppmv. & ppmv & ppmv & $\mathrm{mg} / \mathrm{h}$ \\
\hline \multicolumn{3}{|c|}{ Action Level ${ }^{3,4}$} & 30000 & 8000 & N/A & N/A & N/A & N/A & N/A \\
\hline Tanks & $\begin{array}{c}\text { Watch } \\
\text { List }^{5}\end{array}$ & $\operatorname{Lab}^{6,7}$ & & & & & & & \\
\hline \multirow[t]{3}{*}{$B Y-108$} & $F$ & PNL & 1040 & 399 & 640 & $<0.03$ & $<0.02$ & & 13.4 \\
\hline & & ORNL & & & & & & & \\
\hline & & OGIST & & 399 & 641 & . & & & \\
\hline \multirow[t]{2}{*}{ BY-110 } & $F$ & PNL & 401 & $<160$ & 103 & $<0.09$ & $<0.05$ & & 8 \\
\hline & & ORNL & & & & & & & \\
\hline \multirow[t]{3}{*}{$B Y-111$} & $F$ & PNL & 59 & & $<67$ & $<0.15$ & $<0.05$ & & 6.9 \\
\hline & & ORNL & & & & & & & \\
\hline & & OGIST & & 67 & 98.9 & & & & \\
\hline \multirow[t]{2}{*}{ BY-112 } & $\mathrm{F}$ & PNL & 63 & $<94$ & 40 & 0.18 & $<0.02$ & & 11.2 \\
\hline & & ORNL & & & & & & & \\
\hline \multirow[t]{3}{*}{ C-101 } & & PNL & 98 & & & 1.5 & $<0.04$ & & 30.1 \\
\hline & & ORNL & & & & & & & \\
\hline & & OGIST & & 436 & 642 & & & & \\
\hline \multirow[t]{3}{*}{ C-102 } & 0 & PNL & 189 & 158 & 132 & 0.24 & $<0.05$ & & 20.4 \\
\hline & & ORNL & & & & & & & \\
\hline & & OGIST & & 133 & 154 & & & & \\
\hline \multirow[t]{3}{*}{$C-103$} & 0 & PNL & 304 & & & 1.5 & $<0.06$ & & 42.2 \\
\hline & & ORNL & & & & & & & \\
\hline & & OGIST & & 782 & 763 & & & & \\
\hline \multirow[t]{3}{*}{$C-104$} & & PNL & 44 & & & 0.37 & $<0.02$ & & 12.9 \\
\hline & & ORNL. & & & & & & & \\
\hline & & OGIST & & 68 & 64 & & & & \\
\hline \multirow[t]{3}{*}{ C-105 } & & PNL & 2.4 & & & $<0.1$ & $<0.1$ & & 6.8 \\
\hline & & ORNL & & & & & & & \\
\hline & & OGIST & & 22 & 5.3 & & & & \\
\hline \multirow[t]{2}{*}{ C-106 } & $\mathrm{HH}$ & PNL & $<9$ & & & $<0.1$ & $<0.1$ & & 17.8 \\
\hline & & ORNL & & & & & & & \\
\hline
\end{tabular}


WHC-SD-WM-ER-514 Rev. 1

\begin{tabular}{|c|c|c|c|c|c|c|c|c|c|}
\hline \multicolumn{3}{|c|}{ Analyte } & Ammonia & Hydrogen & $\begin{array}{c}\text { Nitrous } \\
\text { Oxide }\end{array}$ & $\begin{array}{l}\text { Nitric } \\
\text { Oxide }\end{array}$ & $\begin{array}{l}\text { Nitrogen } \\
\text { Dioxide }\end{array}$ & $\begin{array}{c}\text { Hydrogen } \\
\text { Cyanide }\end{array}$ & $\begin{array}{l}\text { Water } \\
\text { Vapor }\end{array}$ \\
\hline \multicolumn{3}{|c|}{ Units $^{2}$} & ppmv & ppmv & ppmv & ppmv & Ppmv & ppmv & $\mathrm{mg} / \mathrm{L}$ \\
\hline \multicolumn{3}{|c|}{ Action Level ${ }^{3,4}$} & 30000 & 8000 & N/A & N/A & $N / A$ & N/A & N/A \\
\hline \multirow[t]{2}{*}{ Tanks } & $\begin{array}{c}\text { Watch } \\
\text { List }^{5}\end{array}$ & $\mathrm{Lab}^{6,7}$ & & . & & & & & \\
\hline & & OGIST & & 9.7 & 3.7 & & & & \\
\hline \multirow[t]{3}{*}{ C-107 } & & PNL & 84 & $<80$ & 41 & 0.2 & $<0.02$ & & 58.8 \\
\hline & & ORNL & & & & & & & \\
\hline & & OGIST & & 230 & 78 & & & & \\
\hline \multirow[t]{3}{*}{$C-108$} & $F$ & PNL & 2.7 & & & 0.24 & $<0.04$ & $<0.0002$ & 17.5 \\
\hline & & ORNL & & & & & & & \\
\hline & & OGIST & & 15.3 & 344 & & & & \\
\hline \multirow[t]{3}{*}{ C-109 } & $F$ & PNL & 10.1 & & & 0.51 & $<0.06$ & & 20.4 \\
\hline & & ORNL & & & & & & & \\
\hline & & OGIST & & 125 & 369 & & & & \\
\hline \multirow[t]{3}{*}{$\mathrm{C}-110$} & & PNL & 124 & $<94$ & 21 & 0.08 & $<0.06$ & & 12.4 \\
\hline & & ORNL & & & & & & & \\
\hline & & OGIST & & 12 & 9.4 & & & & \\
\hline \multirow[t]{3}{*}{$\mathrm{C}-111$} & $F$ & PNL & 5.6 & & & 0.62 & $<0.08$ & $<0.01$ & 22.2 \\
\hline & & ORNL & & & & & & & \\
\hline & & OGIST & & 12.4 & 99.3 & & & & \\
\hline \multirow[t]{3}{*}{$C-112$} & $F$ & PNL & 22.7 & & & 0.62 & $<0.02$ & $<0.01$ & 22.3 \\
\hline & & ORNL & & & & & & & \\
\hline & & OGIST & & 204 & 544 & & & & \\
\hline \multirow[t]{2}{*}{ S-102 } & $O \& H$ & PNL & 412 & 669 & 509 & $<0.04$ & $<0.02$ & & 14.1 \\
\hline & & ORNL & & & & & & & \\
\hline \multirow[t]{2}{*}{ S-111 } & O\&H & PNL & 122 & 391 & 48 & $<0.07$ & $<0.01$ & & 11 \\
\hline & & ORNL & & & & & & & \\
\hline \multirow[t]{2}{*}{$s X-103$} & $O \& H$ & PNL & 77 & $<23$ & $<23$ & $<0.03$ & $<0.01$ & & \\
\hline & & ORNL & & & & & & & \\
\hline \multirow[t]{2}{*}{$5 x-106$} & $O \& H$ & PNL & 179 & $<98$ & 14 & $<0.02$ & $<0.02$ & & 14.9 \\
\hline & & ORNL & & & & & & & \\
\hline
\end{tabular}


WHC-SD-WM-ER-514 Rev. 1

\begin{tabular}{|c|c|c|c|c|c|c|c|c|c|}
\hline \multicolumn{3}{|c|}{ Analyte } & Ammonia & Hydrogen & $\begin{array}{l}\text { Nitrous } \\
\text { Oxide }\end{array}$ & $\begin{array}{l}\text { Nittic } \\
\text { Oxide }\end{array}$ & $\begin{array}{l}\text { Nitrogen } \\
\text { Dioxide }\end{array}$ & $\begin{array}{l}\text { Hydrogen } \\
\text { Cyanide }\end{array}$ & $\begin{array}{l}\text { Water } \\
\text { Vapor }\end{array}$ \\
\hline \multicolumn{3}{|c|}{ Units $^{2}$} & ppmv & ppmv & ppmv & ppmv & ppmv & ppmv & $\mathrm{mg} / \mathrm{L}$ \\
\hline \multicolumn{3}{|c|}{ Action Level ${ }^{3,4}$} & 30000 & 8000 & N/A & $N / A$ & N/A & N/A & N/A \\
\hline Tanks & $\begin{array}{l}\text { Watch } \\
\text { List }^{5}\end{array}$ & $\operatorname{Lab}^{8,7}$ & & $\because$ & & & & & \\
\hline $\mathrm{T}-107$ & $F$ & PNL & 125 & $<94$ & 41.5 & $<0.05$ & $<0.03$ & & 12.1 \\
\hline & & ORNL & & & & & & & \\
\hline \multirow[t]{2}{*}{$\mathrm{T}-111$} & 0 & PNL & 226 & $<94$ & $<12.6$ & $<0.06$ & $<0.09$ & & \\
\hline & & ORNL & & & & & & & \\
\hline \multirow[t]{2}{*}{$T X-105$} & 0 & PNL & 20 & $<99$ & 12.8 & 1.04 & $<0.02$ & & 13.2 \\
\hline & & ORNL & & & & & & & \\
\hline \multirow[t]{3}{*}{$T X-118$} & $F \& O$ & PNL & 33 & $<94$ & 29 & 0.42 & $<0.03$ & $<0.02$ & 8 \\
\hline & & ORNL & & & & & & & \\
\hline & & OGIST & & 97 & 17 & & & & \\
\hline \multirow[t]{2}{*}{ TY-101 } & $\mathrm{F}$ & PNL & 16 & $<93$ & 98 & 0.11 & $<0.04$ & $<0.01$ & 10.3 \\
\hline & & ORNL & & & & & & & \\
\hline \multirow[t]{2}{*}{ TY-103 } & $F$ & PNL & 49 & $<93$ & 159 & 0.1 & $<0.06$ & $<0.01$ & 11.6 \\
\hline & & ORNL & & & & & & & \\
\hline \multirow[t]{2}{*}{ TY-104 } & $F \& O$ & PNL & 61 & $<49$ & 98 & 0.18 & $<0.02$ & & $\uparrow 1.8$ \\
\hline & & ORNL & & & & & & & \\
\hline \multirow[t]{2}{*}{$\mathrm{U}-103$} & $O \& H$ & PNL & 730 & 555 & 878 & $<0.03$ & $<0.02$ & & 12.2 \\
\hline & & ORNL & & & & & & & \\
\hline \multirow[t]{2}{*}{ U-105 } & $O \& H$ & PNL & 325 & $<49$ & 154 & $<0.03$ & $<0.002$ & & 11.9 \\
\hline & & ORNL & & & & & & & \\
\hline \multirow[t]{2}{*}{ U-106 } & 0 & PNL & 988 & 210 & 559 & $<0.04$ & $<0.04$ & & 12.9 \\
\hline & & ORNL & & & & & & & \\
\hline \multirow[t]{2}{*}{ U-107 } & $\mathrm{O} \& \mathrm{H}$ & PNL & 453 & 500 & 701 & $<0.06$ & $<0.03$ & & 11.4 \\
\hline & & ORNL & & & & & & & \\
\hline \multirow[t]{2}{*}{ U-111 } & 0 & PNL & 676 & 247 & 327 & $<0.04$ & $<0.01$ & & 11.3 \\
\hline & & ORNL & & & & & & & \\
\hline \multirow[t]{2}{*}{$U-203$} & 0 & PNL SUMMA ${ }^{T M}$ & & $<25$ & $<25$ & & & & \\
\hline & & PNL Sorbent & 0.9 & & & $<0.05$ & $<0.05$ & & 11.7 \\
\hline
\end{tabular}


WHC-SD-WM-ER-514 Rev. 1

\begin{tabular}{|c|c|c|c|c|c|c|c|c|c|}
\hline \multicolumn{3}{|c|}{ Analyte } & Ammonia & Hydrogen & $\begin{array}{l}\text { Nitrous } \\
\text { Oxide }\end{array}$ & $\begin{array}{l}\text { Nitric } \\
\text { Oxide }\end{array}$ & $\begin{array}{c}\text { Nitrogen } \\
\text { Dioxide }\end{array}$ & $\begin{array}{l}\text { Hydrogen } \\
\text { Cyanide }\end{array}$ & $\begin{array}{l}\text { Water } \\
\text { Vapor }\end{array}$ \\
\hline \multicolumn{3}{|c|}{ Units $^{2}$} & ppmv & ppmv & ppmv & ppmv & ppmv & ppmv & $\mathrm{mg} / \mathrm{L}$ \\
\hline \multicolumn{3}{|c|}{ Action Level ${ }^{3,4}$} & 30000 & 8000 & N/A & N/A & N/A & N/A & $N / A$ \\
\hline Tanks & $\begin{array}{l}\text { Watch } \\
\text { List }^{5}\end{array}$ & $\operatorname{Lab} b^{8,7}$ & & & & & & & \\
\hline \multirow[t]{2}{*}{ U-204 } & 0 & PNL SUMMA ${ }^{\mathrm{MM}}$ & & $<25$ & $<25$ & & & & \\
\hline & & PNL Sorbent & 0.1 & & & $<0.01$ & $<0.02$ & & 15.9 \\
\hline Average $^{8}$ & & & 222 & 246 & 235 & 0.4 & 0.05 & - & - \\
\hline Median & & & 81 & 204.00 & 98.90 & 0.24 & 0.05 & - & -- \\
\hline Minimum & & & 0.1 & 9.7 & 3.7 & 0.08 & 0.05 & - & - \\
\hline Maximum & & & 1040 & 782 & 878 & 1.50 & 0.05 & - & $\ldots$ \\
\hline
\end{tabular}


WHC-SD-WM-ER-514 Rev. 1

\begin{tabular}{|c|c|c|c|c|c|c|c|}
\hline \multicolumn{3}{|c|}{ Analyte } & $\mathrm{n}$-Undecane & n-Dodecane & n-Tridecane & Tetradecane & $\mathrm{NPH}$ \\
\hline \multicolumn{3}{|c|}{ Units $^{2}$} & $\mathrm{mg} / \mathrm{m} 3$ & $\mathrm{mg} / \mathrm{m} 3$ & $\mathrm{mg} / \mathrm{m} 3$ & $\mathrm{mg} / \mathrm{m} 3$ & $\mathrm{mg} / \mathrm{m} 3$ \\
\hline \multicolumn{3}{|c|}{ Action Level ${ }^{3,4}$} & 9600 & 9200 & 9200 & 8800 & $\sim 9600$ \\
\hline Tanks & $\begin{array}{c}\text { Watch } \\
\text { List }^{5}\end{array}$ & $\operatorname{Lab}^{6.7}$ & & & & & \\
\hline \multirow[t]{3}{*}{ A-101 } & $O \& \times H$ & PNL SUMMATM & 0.06 & 0.09 & 0.09 & & 0.24 \\
\hline & & PNL Sorbent & 0.12 & 0.56 & 1.04 & 0.52 & 2.24 \\
\hline & & ORNL TST & 0.10 & 0.36 & 0.84 & 0.51 & 1.81 \\
\hline \multirow[t]{3}{*}{$A X-102$} & 0 & PNL SUMMA ${ }^{T M}$ & & & & & \\
\hline & & PNL Sorbent & 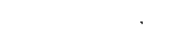 & 0.084 & 0.22 & 0.091 & 0.395 \\
\hline & & ORNL TST & 0.03 & 0.075 & 0.3 & 0.12 & 0.525 \\
\hline \multirow[t]{2}{*}{ B-103 } & 0 & PNL & 0.16 & 0.7 & 1.67 & 0.95 & 3.48 \\
\hline & & ORNL & 0.091 & 0.281 & 1.0 & 0.72 & 2.1 \\
\hline \multirow[t]{2}{*}{$B X-104$} & & PNL & 1.61 & 6.92 & 8.11 & 0.75 & 17.39 \\
\hline & & ORNL & 1.81 & 64.5 & 16.5 & 3.61 & 86.4 \\
\hline \multirow[t]{3}{*}{ BY-103 } & $F$ & PNL & & 0.21 & 0.51 & 0.55 & \\
\hline & & ORNL & $<0.036$ & 0.13 & 0.24 & 0.39 & 0.75 \\
\hline & & OGIST & & & & & \\
\hline \multirow[t]{3}{*}{ BY-104 } & $F$ & PNL & 0.37 & 1.58 & 0.22 & 0.13 & 2.3 \\
\hline & & ORNL & 0.61 & 0.44 & 0.69 & 0.23 & 1.97 \\
\hline & & OGIST & & & & & \\
\hline \multirow[t]{3}{*}{ BY-105 } & $\mathbf{F}$ & PNL & & 0.09 & 0.14 & 0.13 & 0.36 \\
\hline & & ORNL & 0.09 & 0.061 & 0.082 & 0.02 & 0.253 \\
\hline & & OGIST & & & & & \\
\hline \multirow[t]{3}{*}{ BY-106 } & $F$ & PNL & 0.06 & 0.09 & 0.09 & & 0.24 \\
\hline & & ORNL & 0.005 & 0.049 & 0.057 & 0.045 & 0.156 \\
\hline & & OGIST & & & & & \\
\hline \multirow[t]{3}{*}{ BY -107} & $F$ & PNL & 0.71 & 1.47 & & 1.12 & \\
\hline & & ORNL & 1.0 & 1.6 & 2.1 & 5.01 & 9.7 \\
\hline & & OGIST & & & & & \\
\hline$B Y-108$ & $\mathrm{~F}$ & PNL & 3.34 & 6.16 & 5.3 & 1.95 & \\
\hline
\end{tabular}


WHC-SD-WM-ER-514 Rev. 1

\begin{tabular}{|c|c|c|c|c|c|c|c|}
\hline \multicolumn{3}{|c|}{ Analyte } & $\mathrm{n}$-Undecane & n-Dodecane & n-Tridecane & Tetradecane & NPH \\
\hline \multicolumn{3}{|c|}{ Units $^{2}$} & $\mathrm{mg} / \mathrm{m} 3$ & $\mathrm{mg} / \mathrm{m} 3$ & $\mathrm{mg} / \mathrm{m} 3$ & $\mathrm{mg} / \mathrm{m} 3$ & $\mathrm{mg} / \mathrm{m} 3$ \\
\hline \multicolumn{3}{|c|}{ Action Level ${ }^{3.4}$} & 9600 & 9200 & 9200 & 8800 & $\sim 9600$ \\
\hline \multirow[t]{3}{*}{ Tanks } & $\begin{array}{c}\text { Watch } \\
\text { Lisi.. }\end{array}$ & $\operatorname{Lab}^{6,7}$ & & & & & \\
\hline & & ORNL & 3.3 & 6.1 & 6.0 & 8.52 & 23.9 \\
\hline & & OGIST & & & & & \\
\hline \multirow[t]{2}{*}{$B Y-110$} & $\mathrm{~F}$ & PNL & & & & 0.25 & 0.3 \\
\hline & & ORNL & 0.29 & 0.60 & 1.1 & 0.4 & 2.4 \\
\hline \multirow[t]{3}{*}{$B Y-111$} & $\mathrm{~F}$ & PNL & 0.07 & 0.09 & 0.07 & & \\
\hline & & ORNL & $<0.0022$ & 0.0035 & 0.012 & & 0.016 \\
\hline & & OGIST & & & & & \\
\hline \multirow[t]{2}{*}{$B Y-112$} & $F$ & PNL & & & & & \\
\hline & & ORNL & 0.043 & 0.074 & 0.16428 & 0.1 & 0.38 \\
\hline \multirow[t]{3}{*}{ C-101 } & & PNL & 6.5 & 13.6 & 7.04 & 0.17 & 27.27 \\
\hline & & ORNL & 3.2 & 7.1 & 5.0 & & 15.3 \\
\hline & & OGIST & & & & & \\
\hline \multirow[t]{3}{*}{$C-102$} & 0 & PNL & 11.3 & 12.3 & 12.1 & 4.4 & 40.1 \\
\hline & & ORNL & 9.8 & 14 & 13 & 9.06 & 45.86 \\
\hline & & OGIST & & & & & \\
\hline \multirow[t]{3}{*}{ C-103 } & 0 & PNL & 21.2 & 273 & 360 & 63 & 717 \\
\hline & & ORNL & 27 & 261 & 365 & 75 & 728 \\
\hline & & OGIST & & & & & \\
\hline \multirow[t]{3}{*}{ C-104 } & & PNL & 4.9 & 6.5 & 6.2 & 0.96 & 18.5 \\
\hline & & ORNL & 0.902 & 0.55 & 0.65 & & 2.1 \\
\hline & & OGIST & & & & & \\
\hline \multirow[t]{3}{*}{ C-105 } & & PNL & 0.22 & 0.29 & 0.27 & & 0.78 \\
\hline & & ORNL & 0.43 & 0.12 & 0.16 & 0.14 & 0.85 \\
\hline & & OGIST & & & & & \\
\hline \multirow[t]{3}{*}{$C-106$} & $\mathrm{HH}$ & PNL & & & 0.13 & & 0.13 \\
\hline & & ORNL & 0.0024 & 0.027 & 0.071 & 0.11 & 0.21 \\
\hline & & OGIST & & & & & \\
\hline
\end{tabular}


WHC-SD-WM-ER-514 Rev. 1

\begin{tabular}{|c|c|c|c|c|c|c|c|}
\hline \multicolumn{3}{|c|}{ Analyte } & n-Undecane & n-Dodecane & n-Tridecane & Tetradecane & NPH \\
\hline \multicolumn{3}{|c|}{ Units $^{2}$} & $\mathrm{mg} / \mathrm{m} 3$ & $\mathrm{mg} / \mathrm{m} 3$ & $\mathrm{mg} / \mathrm{m} 3$ & $\mathrm{mg} / \mathrm{m} 3$ & $\mathrm{mg} / \mathrm{m} 3$ \\
\hline \multicolumn{3}{|c|}{ Action Level 3,4} & 9600 & 9200 & 9200 & 8800 & -9600 \\
\hline Tanks & $\begin{array}{c}\text { Watch } \\
\text { List }^{5}\end{array}$ & $L a b^{0,7}$ & & & & & \\
\hline \multirow[t]{3}{*}{ C-107 } & & PNL & & 0.24 & 1.18 & 0.46 & \\
\hline & & ORNL & 0.039 & 0.055 & 0.076 & 0.025 & 0.19 \\
\hline & & OGIST & & & & & \\
\hline \multirow[t]{3}{*}{$C-108$} & $F$ & PNL & & & & & \\
\hline & & ORNL & & 0.0040 & 0.0090 & 0.002 & 0.015 \\
\hline & & OGIST & & & & & \\
\hline \multirow[t]{3}{*}{$C-109$} & $\mathrm{~F}$ & PNL & & & & & \\
\hline & & ORNL & & 0.0020 & 0.0039 & 0.004 & 0.0098 \\
\hline & & OGIST & & & & & \\
\hline \multirow[t]{3}{*}{$C-\uparrow 10$} & & PNL & 0.28 & 0.59 & 0.55 & 0.3 & \\
\hline & & ORNL & 0.95 & 0.64 & 1.2 & 0.42 & 3.2 \\
\hline & & OGIST & & & & & \\
\hline \multirow[t]{3}{*}{$C-111$} & $\mathrm{~F}$ & PNL & & & & & \\
\hline & & ORNL & & 0.0041 & 0.0099 & & 0.014 \\
\hline & & OGIST & & & & & \\
\hline \multirow[t]{3}{*}{$\mathrm{C}-112$} & $F$ & PNL & & & & & \\
\hline & & ORNL & & 0.0033 & 0.0049 & 0.005 & 0.013 \\
\hline & & OGIST & & & & & \\
\hline \multirow[t]{2}{*}{ S-102 } & $O \& \mathrm{H}$ & PNL & & & & & \\
\hline & & ORNL & 0.018 & 0.024 & 0.054 & & 0.097 \\
\hline \multirow[t]{2}{*}{ S-111 } & $O \& H$ & PNL & & & & & \\
\hline & & ORNL & 0.0018 & 0.0016 & 0.0029 & 0.00044 & 0.007 \\
\hline \multirow[t]{2}{*}{$s x-103$} & $\mathrm{O} \& \mathrm{H}$ & PNL & & & & & \\
\hline & & ORNL & 0.0020 & 0.0017 & 0.0042 & & 0.008 \\
\hline \multirow[t]{2}{*}{$s x-106$} & $\mathrm{O} \& \mathrm{H}$ & PNL & & & & & \\
\hline & & ORNL & 0.0036 & 0.0031 & 0.0043 & 0.0028 & 0.014 \\
\hline$T-107$ & $F$ & PNL & & & & & \\
\hline
\end{tabular}


WHC-SD-WM-ER-514 Rev. 1

\begin{tabular}{|c|c|c|c|c|c|c|c|}
\hline \multicolumn{3}{|c|}{ Analyte } & $n$-Undecane & n-Dodecane & n-Tridecane & Tetradecane & $\mathrm{NPH}$ \\
\hline \multicolumn{3}{|c|}{ Units $^{2}$} & $\mathrm{mg} / \mathrm{m} 3$ & $\mathrm{mg} / \mathrm{m} 3$ & $\mathrm{mg} / \mathrm{m} 3$ & $\mathrm{mg} / \mathrm{m} 3$ & $\mathrm{mg} / \mathrm{m} 3$ \\
\hline \multicolumn{3}{|c|}{ Action Level ${ }^{3,4}$} & 9600 & 9200 & 9200 & 8800 & $\sim 9600$ \\
\hline \multirow[t]{2}{*}{ Tanks } & $\begin{array}{c}\text { Watch } \\
\text { List }^{5}\end{array}$ & $\operatorname{Lab}^{8.7}$ & & - & & & \\
\hline & & ORNL & 0.010 & 0.016 & 0.046 & 0.032 & 0.10 \\
\hline \multirow[t]{2}{*}{$\mathrm{T}-111$} & 0 & PNL & 0.10 & 2.94 & 10.85 & 6.00 & 19.89 \\
\hline & & ORNL & 0.093 & 1.42 & 9.43 & 7.65 & \\
\hline \multirow[t]{2}{*}{$T X-105$} & 0 & PNL & & & & & \\
\hline & & ORNL & $<0.00097$ & 0.0053 & 0.0082 & 0.001 & 0.015 \\
\hline \multirow[t]{3}{*}{$T X-118$} & F \& 0 & PNL & & & & & \\
\hline & & ORNL & 0.022 & 0.052 & 0.17 & 0.02 & 0.27 \\
\hline & & OGIST & & & & & \\
\hline \multirow[t]{2}{*}{ TY-101 } & $F$ & PNL & & & & & \\
\hline & & ORNL & 0.0025 & 0.031 & 0.12 & 0.052 & 0.21 \\
\hline \multirow[t]{2}{*}{ TY-103 } & $F$ & PNL & 0.36 & 7.19 & 13.9 & 5.2 & \\
\hline & & ORNL & 0.31 & 6.1 & 32.9 & 14.7 & 54.0 \\
\hline \multirow[t]{2}{*}{ TY-104 } & F \& $O$ & PNL & & & 0.06 & & \\
\hline & & ORNL & 0.0084 & 0.12 & 0.99 & 0.3 & 1.4 \\
\hline \multirow[t]{2}{*}{$U-103$} & $\mathrm{O} \& \mathrm{H}$ & PNL & & & & & \\
\hline & & ORNL & 0.0092 & 0.011 & 0.028 & 0.012 & \\
\hline \multirow[t]{2}{*}{ U-105 } & O\&H & PNL & & & & & \\
\hline & & ORNL & 0.0044 & 0.0088 & 0.038 & & \\
\hline \multirow[t]{2}{*}{ U-106 } & 0 & PNL & & & & & \\
\hline & & ORNL & 0.011 & 0.017 & 0.038 & 0.029 & 0.095 \\
\hline \multirow[t]{2}{*}{ U-107 } & $\mathrm{O} \& \mathrm{H}$ & PNL & & & & & \\
\hline & & ORNL & 0.017 & 0.031 & 0.082 & 0.0056 & 0.14 \\
\hline \multirow[t]{2}{*}{$\mathrm{U}-1 \uparrow 1$} & 0 & PNL & & & & & \\
\hline & & ORNL & 0.0091 & 0.032 & 0.071 & 0.052 & 0.16 \\
\hline \multirow[t]{2}{*}{ U-203 } & 0 & PNL SUMMA ${ }^{\text {TM }}$ & & & & & \\
\hline & & PNL Sorbent & & & & & \\
\hline U-204 & 0 & PNL SUMMA ${ }^{T M}$ & & & & & \\
\hline
\end{tabular}


WHC-SD-WM-ER-514 Rev. 1

\begin{tabular}{|c|c|c|c|c|c|c|c|}
\hline \multicolumn{3}{|c|}{ Analyte } & $\mathrm{n}$-Undecane & n-Dodecane & $\mathrm{n}$-Tridecane & Tetradecane & NPH \\
\hline \multicolumn{3}{|c|}{ Units $^{2}$} & $\mathrm{mg} / \mathrm{m} 3$ & $\mathrm{mg} / \mathrm{m} 3$ & $\mathrm{mg} / \mathrm{m} 3$ & $\mathrm{mg} / \mathrm{m} 3$ & $\mathrm{mg} / \mathrm{m} 3$ \\
\hline \multicolumn{3}{|c|}{ Action Level 3.4} & 9600 & 9200 & 9200 & 8800 & -9600 \\
\hline \multirow[t]{2}{*}{ Tanks } & $\begin{array}{l}\text { Watch } \\
\text { List. }^{5}\end{array}$ & $\operatorname{Lab}^{6,7}$ & & & & & \\
\hline & & PNL Sorbent & & & & & \\
\hline Average $^{8}$ & & & 1.4 & 8.0 & 10.4 & 2.5 & 23.7 \\
\hline Median & & & 0.1 & 0.13 & 0.22 & 0.28 & 0.46 \\
\hline Minimum & & & 0.0018 & 0.0016 & 0.0029 & 0.0004 & 0.0067 \\
\hline Maximum & & & 27 & 273 & 365 & 75 & 728 \\
\hline
\end{tabular}

1. Values in this table have been rounded off for convenience of presentation. Data given within double-line boxes were obtained using the in situ sampling (ISS) method; all other data were obtained using the vapor sampling system (VSS).

2. $p p m v=$ parts per million by volume.

3. Individual action levels were calculated at $20 \%$ of the lower flammability limit.

4. N/A = not applicable.

5. $\mathrm{F}=$ Ferrocyanide, $\mathrm{H}=$ Hydrogen, $\mathrm{HH}=$ High Heat, $\mathrm{O}=$ Organic .

6. $\mathrm{PNL}=$ Pacific Northwest Laboratory, ORNL = Oak Ridge National Laboratory, OGIST = Oregon Graduate Institute of Science and Technology.

7. PNL results should be considered to be the primary organic vapor data for the waste tanks. ORNL analyses of thermal desorption trap samples generally agree with, support, and augment the PNL sample results. A recent audit showed certain WHC quality assurance requirements were not satisfied by ORNL. OGIST results were produced without a WHC-approved quality assurance project plan in place, and should be considered secondary.

8. Averages include only 1 value per tank, and do not include tanks where analytes were below detection limits. PNL data is used when available, and ORNL data is used preferentially to OGIST data. 
WHC-SD-WM-ER-514 Rev. 1

TABLE 2. Toxicology Review Panel Analytes of Concern'

\begin{tabular}{|c|c|c|c|c|c|c|c|c|}
\hline \multicolumn{3}{|c|}{ Anatyte } & Acetonitrile & Ammonia & Benzene & 1,3-Butadiene & n-Butanol & 2-Hexanone \\
\hline \multicolumn{3}{|c|}{ Urits $^{2}$} & ppmv & Ppmv & ppmv & ppmv & ppmv & ppmv \\
\hline \multicolumn{3}{|c|}{ CES (8-hour TWA $)^{3}$} & 20 & 25 & $0.1 / \mathrm{LOQ}$ & $0.19 / \mathrm{LOQ}$ & $\begin{array}{l}50 \text { Ceiling } \\
\text { (Skin) }\end{array}$ & 1 \\
\hline Tanks & $\begin{array}{l}\text { Watch } \\
\text { List }\end{array}$ & $\operatorname{Lab} b^{5,6}$ & & & & & & \\
\hline \multirow[t]{3}{*}{$A-101$} & $O \& H$ & PNL SUMMA ${ }^{\mathrm{TM}}$ & 0.057 & & 0.007 & 0.11 & 4.1 & 0.014 \\
\hline & & PNL Sorbent & & 754 & & & 1.1 & 0.014 \\
\hline & & ORNL TST & 0.16 & & 0.013 & & 2.5 & 0.019 \\
\hline \multirow[t]{3}{*}{$A X-102$} & o & PNL SUMMA ${ }^{\text {TM }}$ & 0.26 & & & & 0.12 & \\
\hline & & PNL Sorbent & 0.16 & 34 & & & & 0.051 \\
\hline & & ORNL TST & 0.15 & & 0.0029 & & 0.18 & 0.013 \\
\hline \multirow[t]{2}{*}{ B-103 } & 0 & PNL & 0.066 & 8.8 & $<0.005$ & $<0.010$ & 0.3 & $<0.010$ \\
\hline & & ORNL & 0.072 & & 0.004 & & 0.2 & 0.0041 \\
\hline \multirow[t]{2}{*}{$B X-104$} & & PNL & 0.052 & 235 & 0.005 & $<0.010$ & 1.7 & 0.034 \\
\hline & & ORNL & 0.34 & & 0.011 & & 4.6 & 0.059 \\
\hline \multirow[t]{3}{*}{ BY-103 } & $F$ & PNL & $<0.005$ & 26 & $<0.005$ & $<0.010$ & 0.75 & $<0.010$ \\
\hline & & ORNL & 0.026 & & 0.0018 & & 2 & 0.0049 \\
\hline & & OGIST & & & & & & \\
\hline \multirow[t]{3}{*}{$B Y-104$} & $\mathrm{~F}$ & PNL & $<0.010$ & 248 & 0.0031 & $<0.010$ & 0.21 & 0.04 \\
\hline & & ORNL & 0.33 & & 0.042 & & 1 & 0.065 \\
\hline & & OGIST & & & & & & \\
\hline \multirow[t]{3}{*}{ BY-105 } & $F$ & $P N L$ & $<0.010$ & 43 & $<0.002$ & $<0.010$ & 0.08 & $<0.010$ \\
\hline & & ORNL & 0.081 & & 0.0069 & & 0.7 & 0.0054 \\
\hline & & OGIST & & & & & & \\
\hline \multirow[t]{3}{*}{ BY-106 } & $F$ & PNL & $<0.010$ & 74 & 0.0022 & $<0.010$ & 0.3 & $<0.010$ \\
\hline & & ORNL & 0.12 & & 0.0073 & & 0.34 & 0.0042 \\
\hline & & OGIST & & & & & & \\
\hline \multirow[t]{3}{*}{ BY -107} & $\mathrm{~F}$ & PNL & $<0.005$ & 972 & 0.0048 & $<0.010$ & 0.81 & 0.069 \\
\hline & & ORNL & 2.2 & & 0.037 & & 7.9 & 0.15 \\
\hline & & OGIST & & & & & & \\
\hline \multirow[t]{3}{*}{$B Y-108$} & $\mathbf{F}$ & PNL & $<0.005$ & 1040 & 0.025 & $<0.010$ & 3.8 & 0.15 \\
\hline & & ORNL & 0.94 & & 0.18 & & 58 & 0.16 \\
\hline & & OGIST & & & & & & \\
\hline BY-110 & $F$ & PNL & $<0.005$ & 401 & $<0.005$ & $<0.010$ & 0.18 & 0.065 \\
\hline
\end{tabular}


WHC-SD-WM-ER-514 Rev. 1

\begin{tabular}{|c|c|c|c|c|c|c|c|c|}
\hline \multicolumn{3}{|c|}{ Analyte } & Acetonitrile & Ammonia & Benzene & 1,3-Butadiene & n-Butanol & 2-Hexanone \\
\hline \multicolumn{3}{|c|}{ Units $^{2}$} & ppmv & ppmv & ppmv & ppmv & ppmv & ppmv \\
\hline \multicolumn{3}{|c|}{ CES (8-hour TWA) ${ }^{3}$} & 20 & 25 & $0.1 / L O Q$ & $0.19 / \mathrm{LOQ}$ & $\begin{array}{l}50 \text { Ceiling } \\
\text { (Skin) }\end{array}$ & 1 \\
\hline \multirow[t]{2}{*}{ Tanks } & $\begin{array}{l}\text { Watch } \\
\text { List }^{4}\end{array}$ & $\operatorname{Lab}^{5,8}$ & & & & & & \\
\hline & & ORNL & 0.81 & & 0.034 & & 0.3 & 0.063 \\
\hline \multirow[t]{3}{*}{ BY-111 } & $F$ & PNL & $<0.005$ & 59 & $<0.005$ & $<0.010$ & 0.051 & 0.018 \\
\hline & & ORNL & 0.05 & & 0.011 & & & \\
\hline & & OGIST & & & & & & \\
\hline \multirow[t]{2}{*}{ BY-112 } & $F$ & PNL & $<0.010$ & 63 & $<0.005$ & $<0.010$ & 0.026 & $<0.010$ \\
\hline & & ORNL & 0.1 & & 0.002 & & 0.059 & 0.0054 \\
\hline C-101 & & PNL & 0.13 & 98 & $<0.002$ & $<0.010$ & 0.23 & 0.06 \\
\hline \multirow[t]{3}{*}{ C-101 } & & PNL & 0.13 & 98 & $<0.002$ & $<0.010$ & 0.23 & 0.06 \\
\hline & & ORNL & 0.69 & & 0.28 & & 0.46 & 0.05 \\
\hline & & OGIST & & & & & & \\
\hline \multirow[t]{3}{*}{$c-102$} & 으. & $\mathrm{PNL}$ & 0.33 & 189 & $<0.005$ & $<0.010$ & 27.82 & 0.73 \\
\hline & & ORNL & 0.68 & & 0.63 & & 15 & 0.14 \\
\hline & & OGIST & & & & & & \\
\hline \multirow[t]{3}{*}{ C-103 } & 으 & PNL & & 304 & & & & \\
\hline & & ORNL & 9.1 & & 0.08 & & 28.4 & 0.51 \\
\hline & & OGIST & 13 & & 0.20 & 0.060 & 13.1 & 0.58 \\
\hline \multirow[t]{3}{*}{$C-104$} & & $\mathrm{PNL}$ & 0.066 & 44 & $<0.002$ & $<0.010$ & 0.74 & $<0.010$ \\
\hline & & ORNL & 0.13 & & 0.0099 & & 2.9 & 0.015 \\
\hline & & OGIST & & & 0.0048 & 0.008 & & \\
\hline \multirow[t]{3}{*}{ C-105 } & & $\mathrm{PNL}$ & $<0.010$ & 2.4 & $<0.002$ & $<0.010$ & 0.052 & $<0.010$ \\
\hline & & ORNL & 0.026 & & 0.00059 & & 0.17 & 0.0011 \\
\hline & & OGIST & & & 0.0005 & 0.0022 & & \\
\hline \multirow[t]{3}{*}{ C-106 } & $\mathrm{HH}$ & PNL & $<0.010$ & $<9$ & $<0.002$ & $<0.010$ & 0.018 & $<0.010$ \\
\hline & & ORNL & 0.0023 & & 0.00022 & & 0.011 & $<0.0001$ \\
\hline & & OGIST & & & 0.00047 & 0.00043 & & \\
\hline \multirow[t]{3}{*}{ C-107 } & & PNL & 0.64 & 84 & $<0.005$ & $<0.010$ & $<0.010$ & $<0.010$ \\
\hline & & ORNL & 0.25 & & $<0.00086$ & & 0.0025 & 0.0013 \\
\hline & & OGIST & & & & & & \\
\hline \multirow[t]{3}{*}{$C-108$} & $F$ & $\mathrm{PNL}$ & $<0.010$ & 2.7 & $<0.002$ & $<0.010$ & $<0.010$ & $<0.010$ \\
\hline & & ORNL & 0.0052 & & 0.00038 & & 0.00049 & 0.00012 \\
\hline & & OGIST & & & & & & \\
\hline \multirow[t]{3}{*}{ C-109 } & $F$ & PNL & 0.082 & 10.1 & $<0.002$ & $<0.010$ & $<0.010$ & $<0.010$ \\
\hline & & ORNL & 0.26 & & 0.00013 & & 0.0032 & 0.00012 \\
\hline & & OGIST & & & & & & \\
\hline \multirow[t]{3}{*}{$C-110$} & & PNL & 0.24 & 124 & $<0.005$ & $<0.010$ & $<0.010$ & $<0.010$ \\
\hline & & ORNL & 0.17 & & 0.016 & & 0.73 & 0.006 \\
\hline & & OGIST & & & & & & \\
\hline C-111 & $\mathrm{F}$ & PNL & $<0.010$ & 5.6 & $<0.002$ & $<0.010$ & $<0.010$ & $<0.010$ \\
\hline
\end{tabular}


WHC-SD-WM-ER-514 Rev. 1

\begin{tabular}{|c|c|c|c|c|c|c|c|c|}
\hline \multicolumn{3}{|c|}{ Analyte } & Acetonitrile & Ammonia & Benzene & 1,3-Butadiene & n-Butanol & 2-Hexanone \\
\hline \multicolumn{3}{|c|}{ Urits $^{2}$} & ppmv & ppmv & ppmv & ppmv & ppmv & ppmv \\
\hline \multicolumn{3}{|c|}{ CES (8-hour TWA) } & 20 & 25 & $0.1 / L O Q$ & $0.19 / \mathrm{LOQ}$ & $\begin{array}{l}50 \text { Ceiling } \\
\text { (Skin) }\end{array}$ & 1 \\
\hline \multirow[t]{3}{*}{ Tanks } & $\begin{array}{l}\text { Watch } \\
\text { List }^{*}\end{array}$ & $\mathrm{Lab}^{5,8}$ & & & & & & \\
\hline & & ORNL & 0.0093 & & 0.00056 & & 0.0016 & 0.00032 \\
\hline & & OGIST & & & & & & \\
\hline \multirow[t]{3}{*}{$\mathrm{C}-112$} & $\mathrm{~F}$ & $\mathrm{PNL}$ & 1.1 & 22.7 & $<0.002$ & $<0.010$ & $<0.010$ & $<0.010$ \\
\hline & & ORNL & 3 & & 0.00011 & & 0.0044 & 0.00031 \\
\hline & & OGIST & & & & & & \\
\hline \multirow[t]{2}{*}{ S-102 } & $\mathrm{O} \& \mathrm{H}$ & $\mathrm{PNL}$ & 0.039 & 412 & 0.019 & $<0.010$ & 0.36 & $<0.010$ \\
\hline & & ORNL & 0.081 & & 0.015 & & 0.39 & 0.0034 \\
\hline \multirow[t]{2}{*}{ S-111 } & $\mathrm{O} \& \mathrm{H}$ & PNL & 0.011 & 122 & & & 0.030 & \\
\hline & & ORNL & 0.021 & & 0.0030 & & 0.059 & 0.00072 \\
\hline \multirow[t]{2}{*}{$s X-103$} & $\mathrm{O} \& \mathrm{H}$ & $\mathrm{PNL}$ & & 77 & & & 0.14 & \\
\hline & & ORNL & 0.0079 & & 0.00070 & & 0.13 & 0.00030 \\
\hline \multirow[t]{2}{*}{$s x-106$} & O\&H & PNL & $<0.010$ & 179 & $<0.005$ & $<0.010$ & 0.12 & $<0.010$ \\
\hline & & ORNL & 0.018 & & 0.00055 & & 0.13 & 0.00026 \\
\hline \multirow[t]{2}{*}{$\mathrm{T}-107$} & $F$ & PNL & 0.17 & 125 & $<0.005$ & $<0.010$ & 0.027 & $<0.010$ \\
\hline & & ORNL & 0.048 & & & & 0.023 & 0.00073 \\
\hline \multirow[t]{2}{*}{$\mathrm{T}-111$} & o & PNL & 0.051 & 226 & & & & \\
\hline & & ORNL & 0.057 & & 0.0046 & & 0.0058 & 0.0069 \\
\hline \multirow[t]{2}{*}{$T X-105$} & 으. & PNL & $<0.005$ & 20 & $<0.005$ & $<0.010$ & $<0.010$ & $<0.010$ \\
\hline & & ORNL & 0.0056 & & $<0.00043$ & & 0.0097 & 0.0011 \\
\hline \multirow[t]{3}{*}{$T X-118$} & $\mathrm{~F} \& \mathrm{O}$ & PNL & $<0.010$ & 33 & $<0.005$ & $<0.010$ & 0.28 & $<0.010$ \\
\hline & & ORNL & 0.046 & & 0.0029 & & 0.27 & 0.0062 \\
\hline & & OGIST & & & & & & \\
\hline \multirow[t]{2}{*}{ TY-101 } & $F$ & PNL & 0.079 & 16 & $<0.005$ & $<0.010$ & $<0.010$ & $<0.010$ \\
\hline & & ORNL & 0.029 & & 0.00022 & & 0.0027 & 0.00033 \\
\hline \multirow[t]{2}{*}{ TY-103 } & $F$ & PNL & 0.075 & 49 & $<0.005$ & $<0.010$ & 0.17 & $<0.010$ \\
\hline & & ORNL & 0.04 & & 0.0047 & & 0.15 & 0.0038 \\
\hline \multirow[t]{2}{*}{ TY-104 } & $\mathrm{F} \& \mathrm{O}$ & PNL & 0.069 & 61 & $<0.005$ & $<0.010$ & 0.03 & $<0.010$ \\
\hline & & ORNL & 0.043 & & 0.00037 & & 0.042 & 0.00081 \\
\hline \multirow[t]{2}{*}{$U-103$} & $O \& H$ & PNL & 0.012 & 730 & 0.0053 & & 0.23 & \\
\hline & & ORNL & 0.16 & & 0.011 & & 0.29 & 0.0026 \\
\hline \multirow[t]{2}{*}{ U-105 } & $\mathrm{O} \& H$ & PNL & 0.017 & 325 & & & 0.033 & \\
\hline & & ORNL & 0.037 & & 0.0017 & & 0.096 & 0.00063 \\
\hline \multirow[t]{2}{*}{ U-106 } & 으 & PNL & $<0.010$ & 988 & $<0.005$ & $<0.010$ & $<0.010$ & $<0.010$ \\
\hline & & ORNL & 0.03 & & 0.0076 & & 0.51 & 0.0028 \\
\hline \multirow[t]{2}{*}{ U-107 } & $\mathrm{O \& H}$ & PNL & $<0.010$ & 453 & 0.032 & $<0.010$ & 0.28 & $<0.010$ \\
\hline & & ORNL & 0.12 & & 0.0029 & & 0.07 & 0.00062 \\
\hline \multirow[t]{2}{*}{ U-111 } & 으 & $\mathrm{PNL}$ & 0.023 & 676 & $<0.005$ & $<0.010$ & $<0.010$ & $<0.010$ \\
\hline & & ORNL & 0.2 & & 0.0057 & & 0.26 & 0.0014 \\
\hline
\end{tabular}


WHC-SD-WM-ER-514 Rev. 1

\begin{tabular}{|c|c|c|c|c|c|c|c|c|}
\hline \multicolumn{3}{|c|}{ Analyte } & Acetonitrile & Ammonia & Benzene & 1,3-Butadiene & n-Butanol & 2-Hexanone \\
\hline \multicolumn{3}{|c|}{ Units $^{2}$} & ppmv & ppmv & ppmv & ppmv & ppmv & ppmv \\
\hline \multicolumn{3}{|c|}{ CES (8-hour TWA) ${ }^{3}$} & 20 & 25 & $0.1 / \mathrm{LOQ}$ & $0.19 / \mathrm{LOQ}$ & $\begin{array}{l}50 \text { Ceiling } \\
\text { (Skin) }\end{array}$ & 1 \\
\hline Tanks & $\begin{array}{l}\text { Watch } \\
\text { List" }\end{array}$ & $\operatorname{Lab}^{5,6}$ & & & & & & \\
\hline \multirow[t]{2}{*}{$U-203$} & 0 & PNL. SUMMA ${ }^{\mathrm{TM}}$ & & & & & & \\
\hline & & PNL Sorbent & & 0.9 & & & & \\
\hline \multirow[t]{2}{*}{ U-204 } & 0 & PNL SUMMA ${ }^{\mathrm{MM}}$ & & & & & & \\
\hline & & PNL Sorbent & & 0.1 & & & 0.011 & \\
\hline & & & & & & & & \\
\hline Average $^{7}$ & & & 0.532 & 222 & 0.0338 & 0.0361 & 1.7 & 0.0495 \\
\hline Median & & & 0.08 & 80.5 & 0.0048 & 0.008 & 0.205 & 0.006 \\
\hline Minimum & & & 0.0023 & 0.1 & 0.0001 & 0.00043 & 0.00049 & 0.00012 \\
\hline Maximum & & & 13 & 1040 & 0.63 & 0.11 & 58 & 0.73 \\
\hline
\end{tabular}


WHC-SD-WM-ER-514 Rev. 1

\begin{tabular}{|c|c|c|c|c|c|c|c|c|}
\hline \multicolumn{3}{|c|}{ Analyte } & $\begin{array}{l}\text { Methylene } \\
\text { Chloride }\end{array}$ & $\begin{array}{c}\text { Nitrous } \\
\text { Oxide }\end{array}$ & Dodecane & Tridecane & $\begin{array}{l}\text { Propane } \\
\text { nitrile }\end{array}$ & $\begin{array}{l}\text { Tributyl } \\
\text { Phosphate }\end{array}$ \\
\hline \multicolumn{3}{|c|}{ Units $^{2}$} & ppmv & ppmv & ppmv & ppmv & ppmv & ppmv \\
\hline \multicolumn{3}{|c|}{ CES (8-hour TWA) ${ }^{3}$} & LOQ & 25 STEL & 120 & 120 & 6 & 0.2 \\
\hline Tanks & $\begin{array}{l}\text { Watch } \\
\text { List' }^{\prime}\end{array}$ & $\operatorname{Lab}^{5,6}$ & & & & & & \\
\hline \multirow[t]{3}{*}{$A-101$} & $O \& H$ & PNL SUMMA ${ }^{\text {TM }}$ & & 218 & 0.012 & 0.011 & 0.016 & \\
\hline & & PNL Sorbent & 0.012 & & 0.074 & 0.13 & 0.019 & \\
\hline & & ORNL TST & $<0.005$ & & 0.048 & 0.10 & 0.034 & \\
\hline \multirow[t]{3}{*}{$A X-102$} & $\mathrm{O}$ & PNL SUMMA ${ }^{T M}$ & $<0.005$ & 50 & & & 0.045 & \\
\hline & & PNL Sorbent & 0.0063 & & 0.011 & 0.026 & 0.075 & \\
\hline & & ORNL TST & $<0.005$ & & 0.0099 & 0.037 & 0.048 & \\
\hline \multirow[t]{2}{*}{ B-103 } & 0 & - PNL & $<0.005$ & 77.5 & $<0.010$ & $<0.010$ & $<0.005$ & \\
\hline & & ORNL & 0.0014 & & 0.037 & 0.12 & 0.011 & \\
\hline \multirow[t]{2}{*}{$B X-104$} & & PNL & $<0.005$ & 143 & 0.91 & 1 & $<0.005$ & \\
\hline & & ORNL & & & 1.12 & 2.01 & 0.07 & \\
\hline \multirow[t]{3}{*}{ BY -103} & $F$ & PNL & $<0.005$ & 17 & 0.028 & 0.062 & $<0.005$ & \\
\hline & & ORNL & & & 0.017 & 0.029 & $<0.0033$ & \\
\hline & & OGIST & & 16.5 & & & & \\
\hline \multirow[t]{3}{*}{ BY-104 } & $F$ & PNL & 0.0018 & & 0.21 & 0.25 & $<0.010$ & \\
\hline & & ORNL & 0.0018 & & 0.058 & 0.084 & 0.016 & 0.00082 \\
\hline & & OGIST & & 201 & & & & \\
\hline \multirow[t]{3}{*}{ BY-105 } & $\mathrm{F}$ & PNL & $<0.002$ & & 0.01 & 0.02 & $<0.010$ & \\
\hline & & ORNL & 0.0052 & & 0.0081 & 0.01 & 0.0017 & 0.00017 \\
\hline & & OGIST & & 49.5 & & & & \\
\hline \multirow[t]{3}{*}{ BY -106} & $F$ & PNL & $<0.002$ & & $<0.010$ & $<0.010$ & $<0.010$ & \\
\hline & & ORNL & 0.00047 & & 0.0065 & 0.0069 & 0.0043 & 0.000044 \\
\hline & & OGIST & & 70.6 & & & & \\
\hline \multirow[t]{3}{*}{$B Y-107$} & $\mathrm{~F}$ & PNL & $<0.005$ & & 0.19 & 0.24 & $<0.005$ & \\
\hline & & ORNL & & & & & 0.047 & \\
\hline & & OGIST & & 621 & 0.21 & 0.26 & & \\
\hline \multirow[t]{3}{*}{ BY-108 } & $F$ & PNL & $<0.005$ & 640 & 0.81 & 0.65 & $<0.005$ & \\
\hline & & ORNL & & & 0.8 & 0.73 & $<0.059$ & \\
\hline & & OGIST & & 641 & & & & \\
\hline \multirow[t]{2}{*}{ BY-110 } & $F$ & PNL & $<0.005$ & 103 & 0.071 & 0.058 & $<0.005$ & \\
\hline & & ORNL & & & 0.079 & 0.13 & 0.025 & \\
\hline BY-111 & $F$ & PNL & $<0.005$ & $<67$ & 0.012 & 0.0085 & $<0.005$ & \\
\hline
\end{tabular}


WHC-SD-WM-ER-514 Rev. 1

\begin{tabular}{|c|c|c|c|c|c|c|c|c|}
\hline \multicolumn{3}{|c|}{ Arnalyte } & $\begin{array}{l}\text { Methyiene } \\
\text { Chloride }\end{array}$ & $\begin{array}{c}\text { Nitrous } \\
\text { Oxide }\end{array}$ & Dodecane & Tridecane & $\begin{array}{c}\text { Propane } \\
\text { nitrile }\end{array}$ & $\begin{array}{c}\text { Tributyl } \\
\text { Phosphate }\end{array}$ \\
\hline \multicolumn{3}{|c|}{ Units $^{2}$} & ppmv & ppmv & ppmv & Ppmv & ppmv & ppmv \\
\hline \multicolumn{3}{|c|}{ CES (8-hour TWA $)^{3}$} & LOQ & 25 STEL & 120 & 120 & 6 & 0.2 \\
\hline \multirow[t]{3}{*}{ Tanks } & $\begin{array}{l}\text { Watch } \\
\text { List }^{4}\end{array}$ & $\operatorname{Lab}^{5,0}$ & & & & & & \\
\hline & & ORNL & & & $<0.00046$ & 0.0015 & 0.0021 & \\
\hline & & OGIST & & 98.9 & & & & \\
\hline \multirow[t]{2}{*}{ BY-112 } & $F$ & PNL & $<0.005$ & 40 & $<0.010$ & $<0.010$ & $<0.005$ & \\
\hline & & ORNL & 0.0016 & & 0.0097 & 0.2 & 0.0024 & \\
\hline \multirow[t]{3}{*}{ C-101 } & & PNL & $<0.002$ & & 1.8 & 0.86 & 0.033 & \\
\hline & & ORNL & 0.21 & & 0.94 & 0.61 & 0.086 & 0.0088 \\
\hline & & OGIST & & 642 & & & & \\
\hline \multirow[t]{3}{*}{$\mathrm{C}-102$} & C & PNL & $<0.005$ & 132 & 1.62 & 1.47 & 0.058 & \\
\hline & & ORNL & 0.086 & & 1.8 & 1.3 & 0.085 & 0.054 \\
\hline & & OGIST & & 154 & & & & \\
\hline \multirow[t]{3}{*}{$\mathrm{C}-103$} & O & $\mathrm{PNL}$ & & & 42 & 51 & & \\
\hline & & ORNL & 1.62 & & 40.3 & 52.0 & 3.3 & 0.51 \\
\hline & & OGIST & 0.18 & 763 & & & 5.2 & \\
\hline \multirow[t]{3}{*}{ C-104 } & & PNL & $<0.002$ & & 0.85 & 0.76 & $<0.010$ & \\
\hline & & ORNL & & & 0.072 & 0.079 & 0.041 & 0.025 \\
\hline & & OGIST & 0.0025 & 64 & & & & \\
\hline \multirow[t]{3}{*}{ C-105 } & & PNL & $<0.002$ & & 0.038 & 0.033 & $<0.010$ & \\
\hline & & ORNL & 0.041 & & 0.016 & 0.019 & 0.0079 & 0.02 \\
\hline & & OGIST & 0.00011 & 5.3 & & & & \\
\hline \multirow[t]{3}{*}{ C-106 } & $\mathrm{HH}$ & PNL & $<0.002$ & & $<0.010$ & 0.017 & $<0.010$ & \\
\hline & & ORNL & 0.092 & & 0.0036 & 0.0087 & $<0.0001$ & 0.013 \\
\hline & & OGIST & 0.0019 & 3.7 & & & & \\
\hline \multirow[t]{3}{*}{ C-107 } & & PNL & $<0.005$ & 41 & 0.032 & 0.14 & $<0.005$ & \\
\hline & & ORNL & 0.14 & & 0.0073 & 0.0092 & 0.064 & \\
\hline & & OGIST & & 78 & & & & \\
\hline \multirow[t]{3}{*}{$\mathrm{C}-108$} & $F$ & PNL & $<0.005$ & & $<0.010$ & $<0.010$ & $<0.005$ & \\
\hline & & ORNL & & & 0.00053 & 0.0011 & & 0.000075 \\
\hline & & OGIST & & 344 & & & & \\
\hline \multirow[t]{3}{*}{$C-109$} & $\mathbf{F}$ & $\mathrm{PNL}$ & $<0.005$ & & $<0.010$ & $<0.010$ & $<0.005$ & \\
\hline & & ORNL & & & 0.00026 & 0.00047 & 0.0013 & \\
\hline & & OGIST & & 369 & & & & \\
\hline \multirow[t]{3}{*}{$\mathrm{C}-110$} & & PNL & $<0.005$ & 21 & 0.078 & 0.067 & 0.03 & \\
\hline & & ORNL & 0.014 & & 0.084 & 0.15 & 0.034 & 0.0022 \\
\hline & & OGIST & & 9.4 & & & & \\
\hline \multirow[t]{3}{*}{$\mathrm{C}-111$} & $F$ & PNL & $<0.005$ & & $<0.010$ & $<0.010$ & $<0.005$ & \\
\hline & & ORNL & & & 0.00054 & 0.0012 & & \\
\hline & & OGIST & & 99.3 & & & & \\
\hline $\mathrm{C}-112$ & $F$ & $\mathrm{PNL}$ & $<0.005$ & & $<0.010$ & $<0.010$ & 0.029 & \\
\hline
\end{tabular}


WHC-SD-WM-ER-514 Rev. 1

\begin{tabular}{|c|c|c|c|c|c|c|c|c|}
\hline \multicolumn{3}{|c|}{ Analyte } & $\begin{array}{c}\text { Methylene } \\
\text { Chloride }\end{array}$ & $\begin{array}{c}\text { Nitrous } \\
\text { Oxide }\end{array}$ & Dodecane & Tridecane & $\begin{array}{c}\text { Propane } \\
\text { nitrile }\end{array}$ & $\begin{array}{l}\text { Tributyl } \\
\text { Phosphate }\end{array}$ \\
\hline \multicolumn{3}{|c|}{ Units ${ }^{2}$} & ppmv & $\mathrm{ppmv}$ & ppmv & ppmv & ppmv & ppmv \\
\hline \multicolumn{3}{|c|}{ CES (8-hour TWA $)^{3}$} & LOQ & 25 STEL & 120 & 120 & 6 & 0.2 \\
\hline \multirow[t]{3}{*}{ Tanks } & $\begin{array}{l}\text { Watch } \\
\text { List }\end{array}$ & $\operatorname{Lab} b^{5,6}$ & & & & & & \\
\hline & & ORNL & & & & & 0.023 & \\
\hline & & OGIST & & 544 & & & & \\
\hline \multirow[t]{2}{*}{ S-102 } & $\mathrm{O} \& \mathrm{H}$ & PNL & $<0.005$ & 509 & $<0.010$ & $<0.010$ & $<0.005$ & \\
\hline & & ORNL & & & 0.0032 & 0.0066 & 0.0063 & \\
\hline \multirow{2}{*}{ S-111 } & O\&H & PNL & & 48 & & & & \\
\hline & & ORNL & 0.000034 & & 0.00012 & 0.00020 & 0.0015 & \\
\hline \multirow[t]{2}{*}{$5 x-103$} & $\mathrm{O} \& \mathrm{H}$ & PNL & & $<23$ & & & & \\
\hline & & ORNL & 0.00040 & & 0.00020 & 0.00050 & 0.00080 & \\
\hline \multirow[t]{2}{*}{ sX-106 } & $\mathrm{O} \& H$ & PNL & $<0.005$ & 14 & $<0.010$ & $<0.010$ & $<0.005$ & \\
\hline & & ORNL & & & 0.00045 & 0.00062 & 0.001 & \\
\hline \multirow[t]{2}{*}{$\mathrm{T}-107$} & $F$ & PNL & $<0.005$ & 41.5 & $<0.010$ & $<0.010$ & $<0.005$ & \\
\hline & & ORNL & 0.00061 & & 0.0021 & 0.0056 & 0.0031 & \\
\hline \multirow{2}{*}{$\mathrm{T}-111$} & 0 & PNL & 0.008 & $<12.6$ & 0.39 & 0.68 & 0.009 & \\
\hline & & ORNL & 0.0033 & & 0.19 & 1.1 & 0.0042 & \\
\hline \multirow[t]{2}{*}{ TX-105 } & 0 & PNL & $<0.002$ & 12.8 & $<0.010$ & $<0.010$ & $<0.005$ & \\
\hline & & ORNL & $<0.0013$ & & 0.0007 & 0.001 & 0.00084 & \\
\hline \multirow[t]{3}{*}{$T X-118$} & $\mathrm{~F} \& \mathrm{O}$ & PNL & $<0.005$ & 29 & $<0.010$ & $<0.010$ & $<0.005$ & \\
\hline & & ORNL & 0.0066 & & 0.0069 & 0.021 & 0.018 & \\
\hline & & OGIST & & 17 & & & & \\
\hline \multirow[t]{2}{*}{ TY-101 } & $F$ & PNL & $<0.005$ & 98 & $<0.010$ & $<0.010$ & 0.006 & \\
\hline & & ORNL & & & 0.0041 & 0.015 & 0.0038 & \\
\hline \multirow[t]{2}{*}{ TY-103 } & $\mathrm{F}$ & PNL & $<0.005$ & 159 & 0.95 & 1.69 & 0.017 & \\
\hline & & ORNL & & & 0.81 & 4 & 0.0088 & \\
\hline \multirow[t]{2}{*}{ TY-104 } & $F \& O$ & PNL & $<0.005$ & 98 & $<0.010$ & 0.0073 & 0.017 & \\
\hline & & ORNL & & & 0.016 & 0.12 & 0.01 & \\
\hline \multirow[t]{2}{*}{$\mathrm{U}-103$} & O\&H & PNL & & 878 & & & 0.0070 & \\
\hline & & ORNL & 0.011 & & 0.0014 & 0.0034 & 0.0092 & \\
\hline \multirow[t]{2}{*}{ U-105 } & O\&H & $\mathrm{PNL}$ & & 154 & & & & \\
\hline & & ORNL & & & 0.0012 & 0.0046 & 0.0029 & \\
\hline \multirow[t]{2}{*}{ U-106 } & 0 & PNL & $<0.005$ & 559 & $<0.010$ & $<0.010$ & $<0.005$ & \\
\hline & & ORNL & & & 0.0022 & 0.0046 & 0.012 & \\
\hline \multirow[t]{2}{*}{ U-107 } & O\&H & PNL & $<0.005$ & 701 & $<0.040$ & $<0.010$ & 0.062 & \\
\hline & & ORNL & 0.0032 & & 0.0041 & 0.01 & 0.0036 & \\
\hline \multirow[t]{2}{*}{ U-111 } & 0 & PNL & $<0.005$ & 327 & $<0.010$ & $<0.010$ & $<0.005$ & \\
\hline & & ORNL & & & 0.0042 & 0.0086 & 0.0073 & 0.0004 \\
\hline \multirow[t]{2}{*}{$\mathrm{U}-203$} & 0 & PNL SUMMA ${ }^{T M}$ & $<0.005$ & & $<25$ & & & \\
\hline & & PNL Sorbent & 0.0078 & & & & & \\
\hline U-204 & 0 & PNL SUMMA ${ }^{\mathrm{TM}}$ & & $<25$ & $<25$ & & & \\
\hline
\end{tabular}


WHC-SD-WM-ER-514 Rev. 1

\begin{tabular}{|c|c|c|c|c|c|c|c|c|}
\hline \multicolumn{3}{|c|}{ Analyte } & $\begin{array}{l}\text { Methylene } \\
\text { Chloride }\end{array}$ & $\begin{array}{l}\text { Nitrous } \\
\text { Oxide }\end{array}$ & Dodecane & Tridecane & $\begin{array}{c}\text { Propane } \\
\text { nitrile }\end{array}$ & $\begin{array}{c}\text { Tributyl } \\
\text { Phosphate }\end{array}$ \\
\hline \multicolumn{3}{|c|}{ Ulnits ${ }^{2}$} & ppmv & ppmv & ppmv & ppmv & ppmv & ppmv \\
\hline \multicolumn{3}{|c|}{ CES (8-hour TWA) ${ }^{3}$} & LOQ & 25 STEL & 120 & 120 & 6 & 0.2 \\
\hline \multirow[t]{2}{*}{ Tanks } & $\begin{array}{l}\text { Watch } \\
\text { List }^{4}\end{array}$ & $L a b^{5,8}$ & & & & & & \\
\hline & & PNL Sorbent & 0.0057 & & & & & \\
\hline & & & & & & & & \\
\hline & & & & & & & & \\
\hline Average $^{7}$ & & & 0.095 & 231 & 1.25 & 1.49 & 0.164 & - \\
\hline & & & & & & & & \\
\hline Median & & & 0.0057 & 98.9 & 0.028 & 0.0475 & 0.016 & - \\
\hline Minimum & & & 0.000034 & 3.7 & 0.00012 & 0.0002 & 0.0008 & - \\
\hline & & & & & & & & \\
\hline Maximum & & & 1.62 & 878 & 42 & 52 & 5.2 & $=$ \\
\hline
\end{tabular}

1. Values in this table have been rounded off for convenience of presentation. Data given within double-line boxes were obtained using the in situ sampling (ISS) method; all other data were obtained using the vapor sampling system (VSS).

2. ppmv = parts per million by volume.

3. $C E S=$ consensus exposure standard; $T W A=$ time weighted average; $L O Q=$ limit of quantitation; $S T E L=$ short term exposure limit.

4. $\mathrm{F}=$ Ferrocyanide, $\mathrm{H}=$ Hydrogen, $\mathrm{HH}=$ High Heat, $\mathrm{O}=$ Organic.

5. PNL = Pacific Northwest Laboratory, ORNL = Oak Ridge National Laboratory, OGIST = Oregon Graduate Institute of Science and Technology.

6. PNL results should be considered to be the primary organic vapor data for the waste tanks. ORNL. analyses of thermal desorption trap samples generally agree with, support, and augment the PNL sample results. A recent audit showed certain WHC quality assurance requirements were not satisfied by ORNL. OGIST results were produced without a WHC-approved quality assurance project plan in place, and should be considered secondary.

7. Averages include only 1 value per tank, and do not include tanks where analytes were below detection limits. PNL data is used when available, and ORNL data is used preferentially to OGIST data. 